\title{
Remote Sensing-Based Estimation of Carbon Sequestration in Hong Kong Country Parks from 1978 to 2004
}

\author{
Claudio O. Delang* and Yu Yi Hang
}

\author{
Department of Geography and Resource Management, The Chinese University of Hong Kong, Shatin, NT, Hong Kong
}

\begin{abstract}
This paper estimates the amount of carbon sequestered by vegetation and soil in the country parks of Hong Kong from 1978 to 2004. It does so by comparing satellite images of each country park from 1978, 1991, 1997, and 2004, and calculating the area of woodland, scrubland, and grassland in each image. The amount of carbon sequestered in both vegetation and soil is then estimated using aggregate data from other studies. This study shows that there was little overall ecological succession in the country parks from 1978 to 2004, but the amount of carbon sequestered doubled during that period. The paper concludes that limitations in the quality of the satellite images and in the data used to quantify the carbon sequestered by vegetation and soil call for more research before this method is used for policy planning.
\end{abstract}

Keywords: Carbon sequestration, remote sensing, country parks, Hong Kong.

\section{INTRODUCTION}

Plants take in atmospheric $\mathrm{CO}_{2}$ and transform it during photosynthesis, distributing it into plant and microbial tissues [1]. According to Johnson [2], the amount of carbon fixed annually by terrestrial vegetation through the photosynthesis process ranges from 100 to $120 \mathrm{Pg}$. Other studies have indicated that the global potential for enhancing carbon storage in forest and agricultural ecosystems is around $60 \times 10^{9}$ tons of carbon per year [3, 4]. The rate at which vegetation absorbs carbon varies during its lifetime. Carbon uptake is rapid when stands are young and leaf area is at its greatest. However, when vegetation matures (and this is especially true for trees) the rate of net uptake of carbon through photosynthesis slows down, as there is an increase in carbon loss through respiration ${ }^{1}[3]$.

The balance between uptake and release - photosynthesis and respiration rates, respectively - is a dynamic one which is influenced by moisture levels, nutrient availability, and temperature. This influences the net ecosystem productivity (NEP) value and, as a result, the sink and source size of an ecosystem. This in turn has an impact on the terrestrial biosphere. One additional factor is the influence of anthropogenic activities such as the modification and conversion of land cover, which often lead to the emission of carbon into the atmosphere. Land-use changes can rapidly release large amounts of carbon into the atmosphere as a result of associated activities such as the burning of biomass or the acceleration of decomposition rates in soil. Vegetation can benefit from this increase in atmospheric $\mathrm{CO}_{2}$ concentration levels, as $\mathrm{CO}_{2}$ is a prerequisite to

*Address correspondence to this author at the Department of Geography and Resource Management, The Chinese University of Hong Kong, Shatin, NT, Hong Kong; Tel: (852) 2609-6646; Fax: (852) 2603-5006;

E-mail: cdelang@cuhk.edu.hk

${ }^{1}$ Cheng [2] indicates that plant respiration releases approximately 40 to 60 Pg C annually. photosynthesis, which can lead to enhanced growth and reduce water loss. All of these processes can alter the fluxes between the biosphere and atmosphere and, thus, influence the potential for carbon sequestration [5].

Another major problem resulting from anthropogenic disturbances is deforestation, which affects the maximum carbon storage capacity of terrestrial vegetation. Deforestation becomes an additional source of $\mathrm{CO}_{2}$ released into the atmosphere and has been estimated to have an emission rate of 1-2 Pg of carbon per year. Fire also contributes a total carbon release flux of 4-7 Pg per year; the majority of this flux is accounted for by the periodic burning of tropical grasslands [6]. Slowing deforestation, combined with an increase in forestation and other management measures could improve forest ecosystem productivity, which would conserve or sequester significant quantities of carbon: forests store $57 \%$ more carbon per hectare than agroforests and $86 \%$ more than pastures [7, 8]. Furthermore, slowing land-use changes and expanding forest areas could conserve approximately 2.9 and $6.5 \mathrm{Pg}$ of carbon per year, respectively [7].

As can be seen from Fig. (1), which shows the amount of carbon for each compartment of storage from terrestrial vegetation, tropical forest accounts for the majority of the terrestrial vegetation carbon sink. The relatively sizeable contribution of grasslands is noteworthy; this is due largely to the fact that grasslands occupy about $20 \%$ of the vegetated land area, contributing about $23 \%$ of both annual carbon flux and total carbon storage. It is also due to the large amount of organic matter maintained in grassland soils, the combination of dry matter to below-ground parts, and the relatively slow rate of decay for soil organic matter [6]. This is an important factor to bear in mind when researching carbon sequestration in Hong Kong, as Hong Kong has many grasslands in hilltop areas and sub-tropical forest areas.

Hopkinson and Stern [9] studied carbon sequestration in Hong Kong and indicated that natural vegetation sequesters between 10 tons (for wooded grassland and bush) and 125 


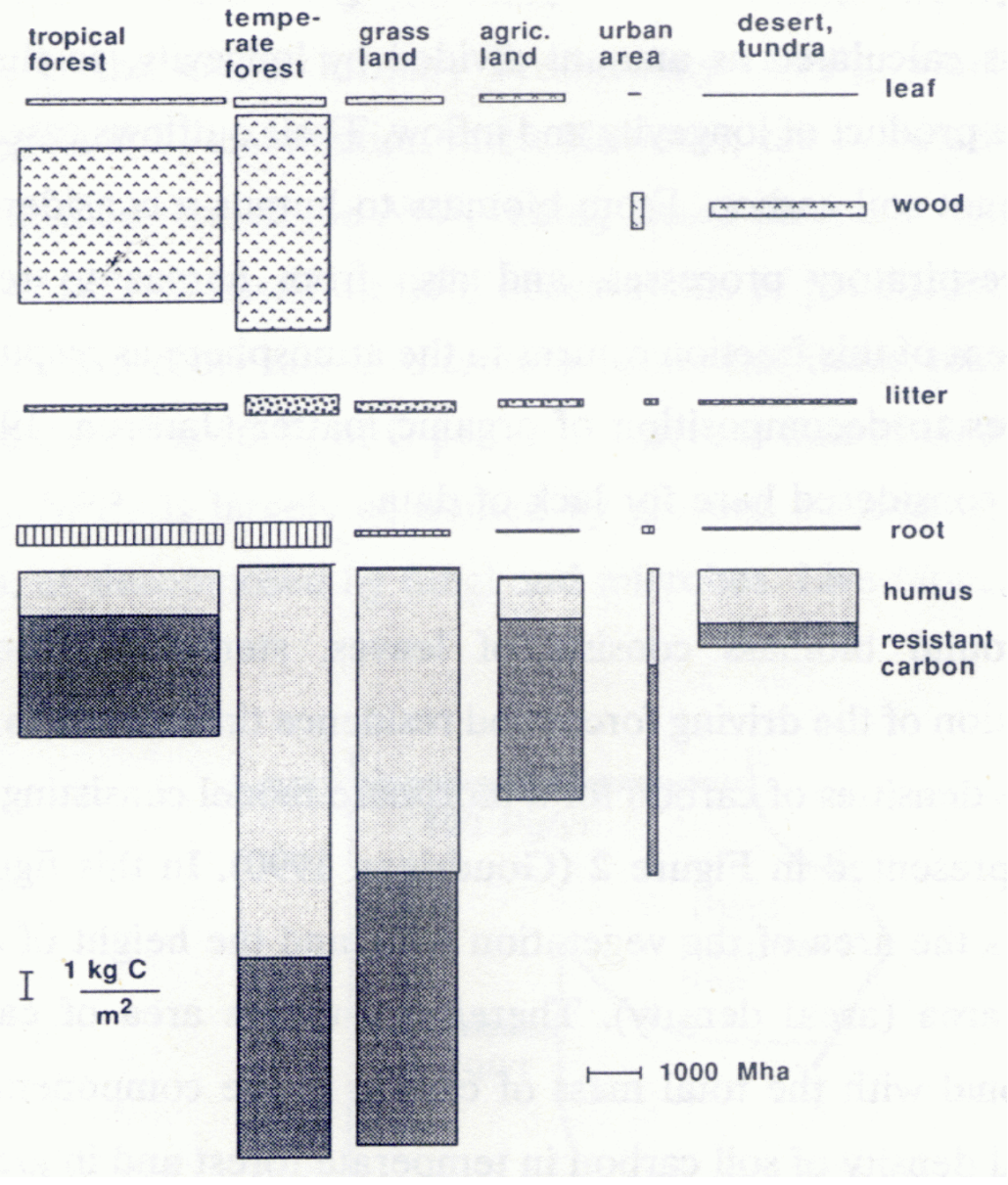

Source: Goudriaan [6].

Fig. (1). Amount of carbon for each storage compartment from terrestrial vegetation.

Note: The width of each bar represents the area covered by the relevant vegetation type, while the height of each bar represents the carbon mass per unit area (areal density). Therefore, the surface area of each bar is proportional to the total mass of carbon for the relevant component.

tons (for secondary closed forest) of carbon per hectare. Woodlands and forests cover approximately 20,000 hectares of Hong Kong. Because most of this area consists of wooded grassland rather than secondary closed forest, Hong Kong is likely to have a relatively low rate of carbon sequestration. Hopkinson and Stern used an average sequestration rate of 15 tons of carbon per hectare and concluded that Hong Kong's terrestrial vegetation sequesters 300,000 tons of carbon per year.

Soil is another very important carbon sink. The amount of carbon in soil is a function of soil-forming factors, including climate, relief, organisms, parent materials, and time [2]. Organic matter (OM) plays a critical role in storing carbon in soils. Soil organic matter (SOM) is a mixture of animal and plant residues (at any stage of decomposition), living and decaying microbial tissue and heterotrophic biomass, and relatively resistant humic substances. The SOM turnover time is relatively long at a global average of 26 years [10]. However, turnover times for different soil organic carbon (SOC) pools is very variable, from a few years for fresh litter to millennia for the most stable OM [11]. Carbon is the main element present in SOM, comprising from $48 \%$ to $60 \%$ of its total weight [12].
Once litter enters the soil, three complementary processes take place: 1) decomposition; 2) humification; and 3) dissolved organic carbon (DOC) formation. During the decomposition process, organic substrates are broken down by a variety of organisms - bacteria in neutral/alkaline soils, and fungi in acid soils. Larger soil animals grind and loosen up the litter, which improves its availability to microbes. During decomposition, in addition to carbon, nutrients are mineralized, with the degree of nitrogen $(\mathrm{N})$ mineralization depending on the $\mathrm{C} / \mathrm{N}$ ratio of the substrate and primary decomposers $-\mathrm{N}$ is a source of food for decomposers [11]. The humification process involves the enrichment of stable compounds during the decomposition of fresh litter [11], and this leads to the sequestration of organic carbon [1]. Whether soil is a source or sink of terrestrial carbon depends on the balance between the oxidation process - aggravated by tilling of the soil in agriculture and land-use changes - and the humification process $[1,12]$.

The aim of this paper is to estimate the amount of carbon stored in the country parks of Hong Kong by looking at both terrestrial vegetation and soil. To do this, it is necessary to classify vegetation and soil types, as different types of vegetation have different sequestration rates. While 


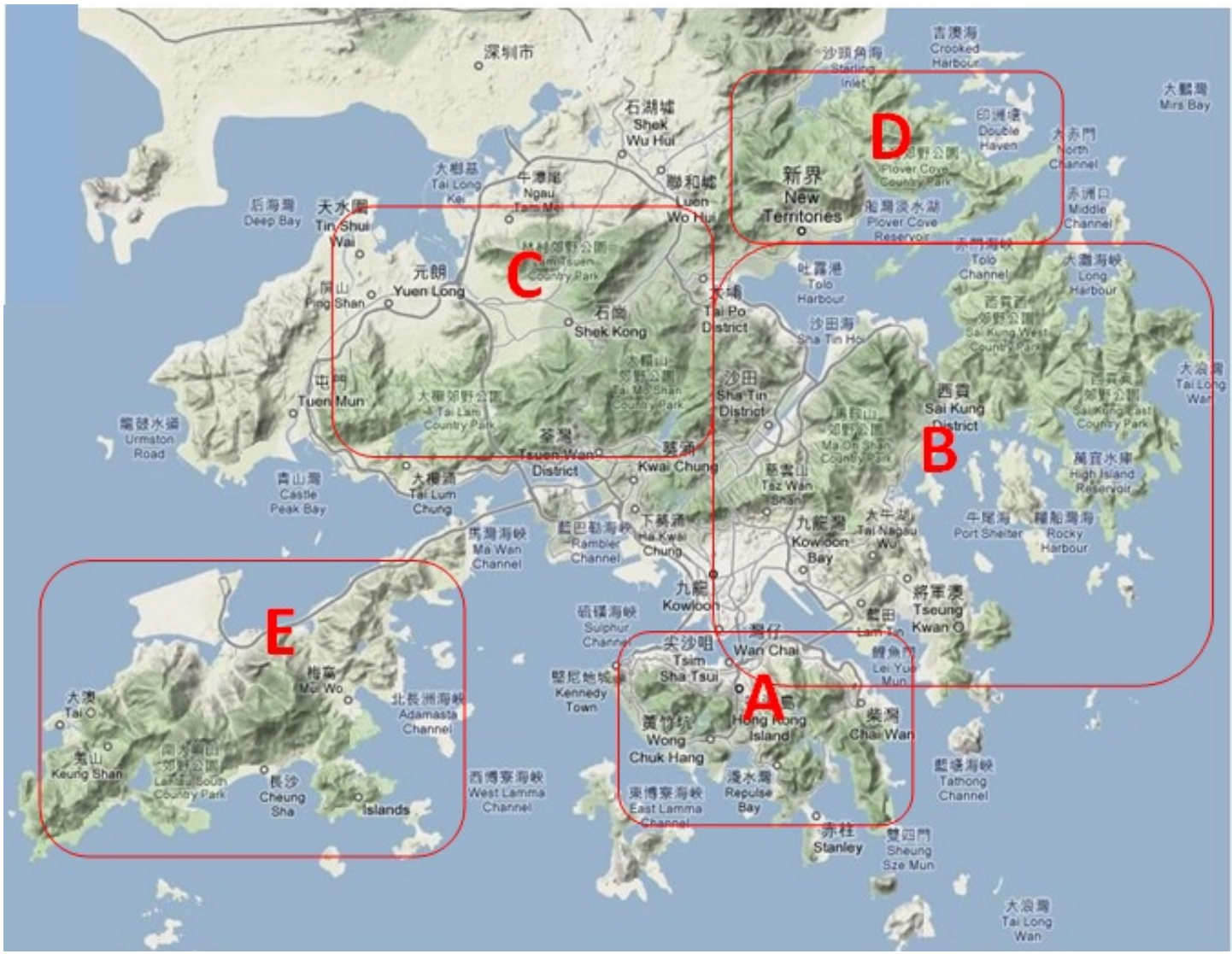

Captured from Google Maps.

Fig. (2). Map of Hong Kong (highlighted areas indicate areas with country parks; see below).

estimating carbon storage at the species level would produce more accurate results, that was not possible due to time and resource constraints.

The next section describes the geographical scope of the study, after which the classification system is introduced. The results are then presented, conclusions are drawn and the limitations of the study are discussed.

\section{STUDY AREA}

The geographical area covered by our study includes all the country parks in Hong Kong (Fig. 2). Hong Kong has 24 country parks and one special area, which together cover a total area of $415.82 \mathrm{~km}^{2}$, corresponding to approximately $40 \%$ of the total landmass of Hong Kong [13]. Hong Kong's country parks were established through the Country Parks Ordinance of 1976. The main objectives envisaged in establishing the country parks were nature conservation, countryside recreation, and outdoor education, while the main purpose of designating the special area was nature conservation. The Agriculture, Fisheries and Conservation Department (AFCD) is responsible for the conservation and management of the parks, including tree planting ${ }^{2}$, litter collection $^{3}$, fire fighting ${ }^{4}$, development control, and the

${ }^{2} \mathrm{AFCD}$ reports indicate that it planted 933,000 trees in the country parks during the 2007/8 financial year [13].

${ }^{3} \mathrm{AFCD}$ reports indicate that it collected 3,100 metric tons of litter during the 2007/8 financial year [13]. provision of educational and recreational facilities. Fig. (2) shows a map of Hong Kong divided into five different areas. The country parks in each area are dealt with individually in the analysis section.

\section{CLASSIFICATION TYPES AND CARBON SEQUESTRATION}

The vegetation of what became the country parks was seriously degraded at the end of WWII. In the late 1970s, the areas concerned were declared country parks and reforested, with any form of exploitation or inhabitation strictly forbidden. Thirty years on, one can find three broad categories of vegetation in the country parks: woodland, scrubland, and grassland. In ideal conditions, the three vegetation types are interrelated, since they form different phases of ecological succession. After the occurrence of hill fires, grasslands emerge in the affected areas, as grasses take a shorter time to grow than other forms of vegetation. However, as time passes, such grasslands are replaced by scrublands, which themselves are eventually superseded by woodlands, as indicated by Thrower [15]. If fires and cutting were totally eliminated from the country parks, most of the grasslands would be replaced by shrubs within five years ${ }^{5}$, and woodlands would replace shrubs within 50 years. As such, woodlands would represent the "climax vegetation" in

\footnotetext{
${ }^{4} \mathrm{AFCD}$ reports indicate that there were 45 hill fire incidents either within or that threatened country parks during the 2007/8 financial year [14].
}

${ }^{5} \mathrm{Scrub}$ is defined as an area of low trees and shrubs. 
Table 1. The Total SOC Vertical Storage by Depth in China (Units: $1 \mathrm{Pg}=10^{15} \mathrm{~g}$ )

\begin{tabular}{|c|c|c|c|c|c|c|c|c|c|c|c|}
\hline \multirow[t]{2}{*}{ Type } & \multirow[t]{2}{*}{ Area $\left(\times 10^{6} \mathrm{ha}\right)$} & \multicolumn{2}{|c|}{$0-10 \mathrm{~cm}$} & \multicolumn{2}{|c|}{$0-20 \mathrm{~cm}$} & \multicolumn{2}{|c|}{$0-30 \mathrm{~cm}$} & \multicolumn{2}{|c|}{$0-50 \mathrm{~cm}$} & \multicolumn{2}{|c|}{$0-100 \mathrm{~cm}$} \\
\hline & & $\left(\times 10^{15} \mathrm{~g}\right)$ & \pm & $\left(\times 10^{15} \mathrm{~g}\right)$ & \pm & $\left(\times 10^{15} \mathrm{~g}\right)$ & \pm & $\left(\times 10^{15} \mathrm{~g}\right)$ & \pm & $\left(\times 10^{15} \mathrm{~g}\right)$ & \pm \\
\hline Water & 15.14 & 0.00 & 0.00 & 0.00 & 0.00 & 0.00 & 0.00 & 0.00 & 0.00 & 0.00 & 0.00 \\
\hline Evergreen broadleaf forest & 1.37 & 0.04 & 0.01 & 0.07 & 0.02 & 0.09 & 0.02 & 0.12 & 0.02 & 0.16 & 0.04 \\
\hline Evergreen needleleaf forest & 31.34 & 1.41 & 0.37 & 2.35 & 0.53 & 2.96 & 0.66 & 4.23 & 1.06 & 4.42 & 1.50 \\
\hline Deciduous broadleaf forest & 6.08 & 0.26 & 0.06 & 0.48 & 0.10 & 0.60 & 0.12 & 0.71 & 0.16 & 0.73 & 0.30 \\
\hline Deciduous needleleaf forest & 1.30 & 0.04 & 0.01 & 0.06 & 0.02 & 0.07 & 0.02 & 0.09 & 0.03 & 0.15 & 0.01 \\
\hline Mixed forest & 20.77 & 0.87 & 0.11 & 1.49 & 0.19 & 1.90 & 0.25 & 2.51 & 0.35 & 2.99 & 0.53 \\
\hline Wooland & 60.78 & 2.58 & 0.69 & 4.46 & 1.26 & 5.27 & 1.35 & 5.38 & 1.20 & 6.59 & 1.84 \\
\hline Woodland grassland & 96.26 & 2.10 & 0.60 & 3.83 & 1.12 & 4.75 & 1.56 & 6.66 & 2.31 & 7.86 & 1.67 \\
\hline Closed shrubland & 0.24 & 0.01 & 0.00 & 0.01 & 0.00 & 0.02 & 0.00 & 0.02 & 0.00 & 0.02 & 0.01 \\
\hline Open shrubland & 216.30 & 1.75 & 0.41 & 3.01 & 0.61 & 4.21 & 0.87 & 6.42 & 1.43 & 10.33 & 2.75 \\
\hline Grassland & 167.19 & 5.75 & 0.78 & 11.00 & 1.55 & 15.23 & 2.22 & 22.01 & 3.81 & 28.96 & 8.03 \\
\hline Cropland & 173.14 & 2.94 & 0.10 & 5.60 & 0.18 & 7.51 & 0.26 & 10.54 & 0.40 & 15.09 & 0.66 \\
\hline Bare Ground & 111.72 & 0.78 & 0.21 & 1.38 & 0.35 & 1.88 & 0.48 & 2.62 & 0.63 & 5.19 & 2.13 \\
\hline Total & 901.63 & 18.51 & 3.35 & 33.74 & 5.93 & 44.48 & 7.80 & 61.30 & 11.39 & 82.48 & 19.46 \\
\hline
\end{tabular}

Source: Wang et al. [18].

a natural process of environmental succession [15]. However, since hill fires occur relatively frequently in Hong Kong, woodland successions are seldom seen. Instead, one can sometimes observe the degradation of woodland to scrubland, grassland and, finally, badland ${ }^{6}[15]$.

Because of time and budgetary constraints it was not possible to do a laboratory analysis of the carbon sequestered by all the plant species and soil types in the Hong Kong country parks. Instead, we use secondary data.

\section{Initial Amount of Carbon}

To start with, we need to estimate the amount of carbon stored by the vegetation, litter, and the soil in 1978, when our analysis starts. As litter and debris (including dead trees, dead roots, fallen wood, and dead fallen leaves and twigs) have a direct relationship with the amount of carbon contained in the soil, carbon in the soil is predominantly related to aboveground biomass. Hence, soil types are here classified in the same ways as vegetation types - forest soil, scrub soil and grassland soil - and the two are summed together.

A study of 140 soil profiles by Vejre et al. [16] shows an average value of $12.5 \mathrm{kgCm}^{-2}(125 \mathrm{tC} / \mathrm{ha})$ for well-drained Danish forest soils. On the other hand, Wang et al. [18] provide several estimates of carbon contents of soil (Table 1), and show the difficulties in giving average data, since the amount of SOC varies enormously not only with soil composition, but also with soil depth. Grigal and Ohmann [17], in a study of forests in the north of the US found an average of $13.9-23.4 \mathrm{kgCm}^{-2}$ (139 to $234 \mathrm{tC} / \mathrm{ha}$ ) for biomass, forest floor, and mineral soil.

${ }^{6}$ Badlands are badly eroded/degraded areas that are not suitable for plant growth.
In spite of these uncertainties, both Vejre et al. [16], Grigal and Ohmann [17], and Wang et al. [18] are in line with the averages of carbon in forest soils provided by Adams [19], in his estimates of average carbon storage in pre-anthropogenic ecosystems (Table 2). Adams [19] suggests an average of $262.5 \mathrm{tC} / \mathrm{ha}$ for tropical woodlands (warm temperate forest, tropical rainforest, monsoon forest, and tropical woodland), $61 \mathrm{tC} /$ ha for tropical scrub, and 54 $\mathrm{tC} / \mathrm{ha}$ for tropical grassland vegetation, litter/debris, and soils. Hong Kong country parks habitats are obviously not pre-anthropogenic, but in the absence of more reliable estimates, we can use them as a starting point to estimate the carbon stored in the soil and vegetation of Hong Kong's country parks.

Adams' [19] data assume that the vegetation and soil are in a steady, undisturbed state in terms of anthropogenic disturbances. However, in most (or all) areas in Hong Kong country parks, human or natural disturbances, such as fires, landslides, water and wind erosion, occur quite frequently and it can be logically expected that the carbon content is much lower than the pre-anthropogenic level. Hence, we tweak the data from Adams, and we assume that in 1978 grassland and scrubland contain $75 \%$ of Adams' [19] preanthropogenic ecosystems (Table 2), i.e. $40.5 \mathrm{tC} / \mathrm{ha}$ for grassland vegetation and soil, and $45.5 \mathrm{tC} / \mathrm{ha}$ for scrubland vegetation and soil. We also assume that in 1978 forests contain $20 \%$ of Adams' pre-anthropogenic ecosystems, i.e. $55.5 \mathrm{tC} / \mathrm{ha}$. We use these figures to estimate the amount of carbon in each vegetation class in 1978, as well as in later years, if that particular vegetation class did not exist in previous years. For example, in 1991 there was no grassland in Shek O (see below), and we use the figure of $40.5 \mathrm{tC} / \mathrm{ha}$ to estimate the amount of carbon sequestered by the 172.8 ha of grassland found in Shek O in 1997. The following section describes how we estimated the yearly increase in carbon. 
Table 2. Estimated Carbon Storage in Pre-Anthropogenic Ecosystems (Error Range +/- 30\%)

\begin{tabular}{|c|c|c|c|c|}
\hline $\begin{array}{c}\text { Ecosystem } \\
\text { Type }\end{array}$ & $\begin{array}{c}\text { Vegetation } \\
\text { (t C/ha) }\end{array}$ & $\begin{array}{c}\text { Soil }^{\mathbf{8}} \\
(\mathbf{t} \text { C/ha) }\end{array}$ & $\begin{array}{c}\text { Litter/Debris }^{\mathbf{9}} \\
\text { (t C/ha) }\end{array}$ & $\begin{array}{c}\text { Total } \\
\text { (t C/ha) }\end{array}$ \\
\hline \hline Warm temperate forest & 190 & 145 & 36 & 371 \\
\hline Tropical rainforest & 210 & 100 & 10 & 320 \\
\hline Monsoon forest & 150 & 100 & 10 & 260 \\
\hline Tropical woodland & 85 & 70 & 10 & 165 \\
\hline Tropical thorn scrub & 40 & 21 & 4 & 65 \\
\hline Tropical grassland & 12 & 42 & 0 & 54 \\
\hline
\end{tabular}

\section{Increase in Carbon}

Carbon is constantly sequestered from the atmosphere by the vegetation and by the soil. However, the rate of carbon sequestration is very difficult to estimate, since each species, and each soil type, have a different rate of uptake of carbon, which in the case of vegetation also changes with age, being highest when the vegetation is young and slowing down as it matures. In the absence of data for Hong Kong, and the presence of a very large number of species (see Tables 3-7 below), we use secondary data to estimate the yearly sequestration of carbon by vegetation and soils.

Very large variations have been observed both at the species level, and at the national or ecosystem level. At the species level, Cannell et al. [20] estimated an annum rate of $2.7 \mathrm{tC} \mathrm{ha}^{-1} \mathrm{yr}^{-1}$ for live wood $P$. sitchensis 25-40 years old, while Cannell [21] reported that an area of Sitka spruce, felled at 55 years, accumulated carbon in live wood, soil and litter at a rate of $3.6 \mathrm{tC} \mathrm{ha}^{-1} \mathrm{yr}^{-1}$. These estimates were much higher than those of Milne and Brown [22], who gave annual sequestration rates of 1.05-1.56 tC/ha for conifers in Britain. At the ecosystem level, Achard et al. [23] estimated an average regrowth rate of $2.75 \mathrm{tC} \mathrm{ha}^{-1} \mathrm{yr}^{-1}$ for tropical forests; Van Kooten et al. [24] found figures for Canada in the range of 0.6 to $0.8 \mathrm{tC} \mathrm{ha}^{-1} \mathrm{yr}^{-1}$; while Brainard et al. [25] found that British forests sequestered $3.5 \mathrm{tC} \mathrm{ha}^{-1} \mathrm{yr}^{-1}$. At the global level, Sedjo and Solomon [26] estimated that forests subtract on average $6.24 \mathrm{tC} \mathrm{ha}^{-1} \mathrm{yr}^{-1}$, while Nordhaus [27] estimated a range of only 0.8 to $1.6 \mathrm{tC} \mathrm{ha}^{-1} \mathrm{yr}^{-1}$.

These studies give a very broad range of figures, from $0.8 \mathrm{tC} \mathrm{ha}^{-1} \mathrm{yr}^{-1}$ to $6.24 \mathrm{tC} \mathrm{ha}^{-1} \mathrm{yr}^{-1}$, with an average of about 3 $\mathrm{tC} \mathrm{ha} \mathrm{hr}^{-1} \mathrm{yr}^{-1}$. Because of a lack of better, site-specific data, in this analysis we use that average figure of $3 \mathrm{tC} \mathrm{ha}^{-1} \mathrm{yr}^{-1}$. In what concerns grassland and scrubland, we assume that the amount of carbon sequestered increases by $0.5 \mathrm{tC} \mathrm{ha}^{-1} \mathrm{yr}^{-1}$. Using these data, we imply that grassland (and its soil) will contain pre-anthropogenic levels of carbon after 28 years, scrubland after 30 years, and forestland after 75 years. Although estimates in the literature vary widely and have a

\footnotetext{
${ }^{7}$ Vegetation includes the leaves, stems, trunks, branches, and roots of vegetation [19].

${ }^{8}$ Soil includes the OM below the litter layer and excludes living or dead roots and underground stems [19].

${ }^{9}$ Litter and debris include dead trees, dead roots, fallen wood, and dead fallen leaves and twigs [19].
}

large range, they seem to be generally in line with the figures we use, though it should be remembered that the constant amounts of carbon sequestration that we use is not entirely correct, since the amount of carbon sequestered by the vegetation - and this is specially true for the trees decreases as the vegetation ages. We hope that future research will improve the data available, and the results presented here.

To estimate changes in carbon sequestration rates in Hong Kong's country parks, four satellite images of each park taken in 1978, 1991, 1997, and 2004 were analyzed by remote sensing.

\section{REMOTE SENSING ANALYSIS}

The data collection process used to calculate the amount of carbon sequestered in the country parks involved two steps: 1) satellite image analysis; and 2) calculating the area covered by each type of vegetation and soil.

Because of its consistency and the wide coverage remote sensing allows, it is used here for the measurement of vegetation types [28]. We use the remote sensing software PCI Geomatica ${ }^{\mathrm{TM}}$ for this analysis. As noted above, satellite images taken in 1978, 1991, 1997, and 2004 were used to estimate carbon sequestration in each park. Images were clipped to set the image boundaries to those of each park, and subsequently classified using the unsupervised classification method.

The area covered by each vegetation type was calculated using to the number of pixels corresponding to it. The pixel sizes varied according to the year in which the image was taken. The 1978 images were taken by a Landsat satellite with $30 \mathrm{~m} \times 30 \mathrm{~m}$ pixels. The 1991, 1997, and 2004 images were taken by a SPOT ${ }^{10}$ satellite. In 1991 and 1997 the pixel size was $20 \mathrm{~m} \times 20 \mathrm{~m}$, while in 2004 it was $10 \mathrm{~m} \times 10 \mathrm{~m}$. The area (in square meters) covered by each vegetation type was calculated by multiplying the number of pixels by the pixel size. The total area was then converted into hectares.

\section{UNSUPERVISED CLASSIFICATION}

Unsupervised classification does not require the user to specify any information about the features contained in the images. This kind of classification is used when there is a lack of ground information and the surface features within the area under observation are not well-defined. Since all the satellite images we examined were taken in the past (hence, all aggregations were based on predictions and estimates of past situations) and no ground-level confirmation was possible, it was a more suitable method for our study than supervised classification.

With unsupervised classification, the program selects class statistics automatically, with the computer assigning spectral signatures to cluster classes selected by the program itself. Hence, the analyst does not specify any type of class prior to running the program. However, numerous classes emerge that the analyst must aggregate into groups - in this case, woodland, scrubland, and grassland. The aggregation process is based solely on the analyst's assumptions.

\footnotetext{
${ }^{10}$ SPOT is the abbreviation for Satellite Pour l'Observation de la Terre.
} 
The advantage of this system is that it minimizes human error, as it does not involve the analyst selecting training sites to represent different classes. Also, unique classes that cover a very small area can be incorporated. However, the disadvantage of this system is that there is no control over the menu of classes, i.e., the clusters can be random and too widespread, which can sometimes result in an excessive number of classes. According to Gibbs et al. [29], since tropical forests are among the most carbon-rich and structurally complex ecosystems in the world, signals from remote-sensing instruments tend to saturate quickly. This affects the reliability of forest carbon stock estimates in such ecosystems. Moreover, remote sensing systems that rely on optical data (visible and infrared light) are further limited in the tropics by cloud cover.

\section{RESULTS}

We discuss our results by geographic area, first providing a brief introduction to all the country parks in each area, and then discussing each individual country park in terms of the classification of its vegetation, the distribution of its vegetation, and the amount of carbon for each category of vegetation and soil.

\section{Country Parks on Hong Kong Island (Box A in Fig. 2)}

Shek O, Tai Tam, Aberdeen, Pok Fu Lam, and Long Fu Shan country parks are located on Hong Kong Island (as shown in Fig. 3). Table 3 records the size of each park and reservoir, and the major species present in each park.

\section{Shek O Country Park}

Shek O Country Park is an ever-changing landscape, as there are frequent landslides and areas that are badly eroded due to its uneven and steep terrain. In 1978 and 1997 grassland covered areas that had become badly eroded, but these same areas were again colonized by scrubland due to natural succession - and possibly the reforestation policies of the AFCD - in 1991 and again in 2004 (Fig. 4).

As the first image taken in 1978 shows, since the park was mainly composed of scrubland and grassland areas, the amount of carbon sequestered at that time was comparatively

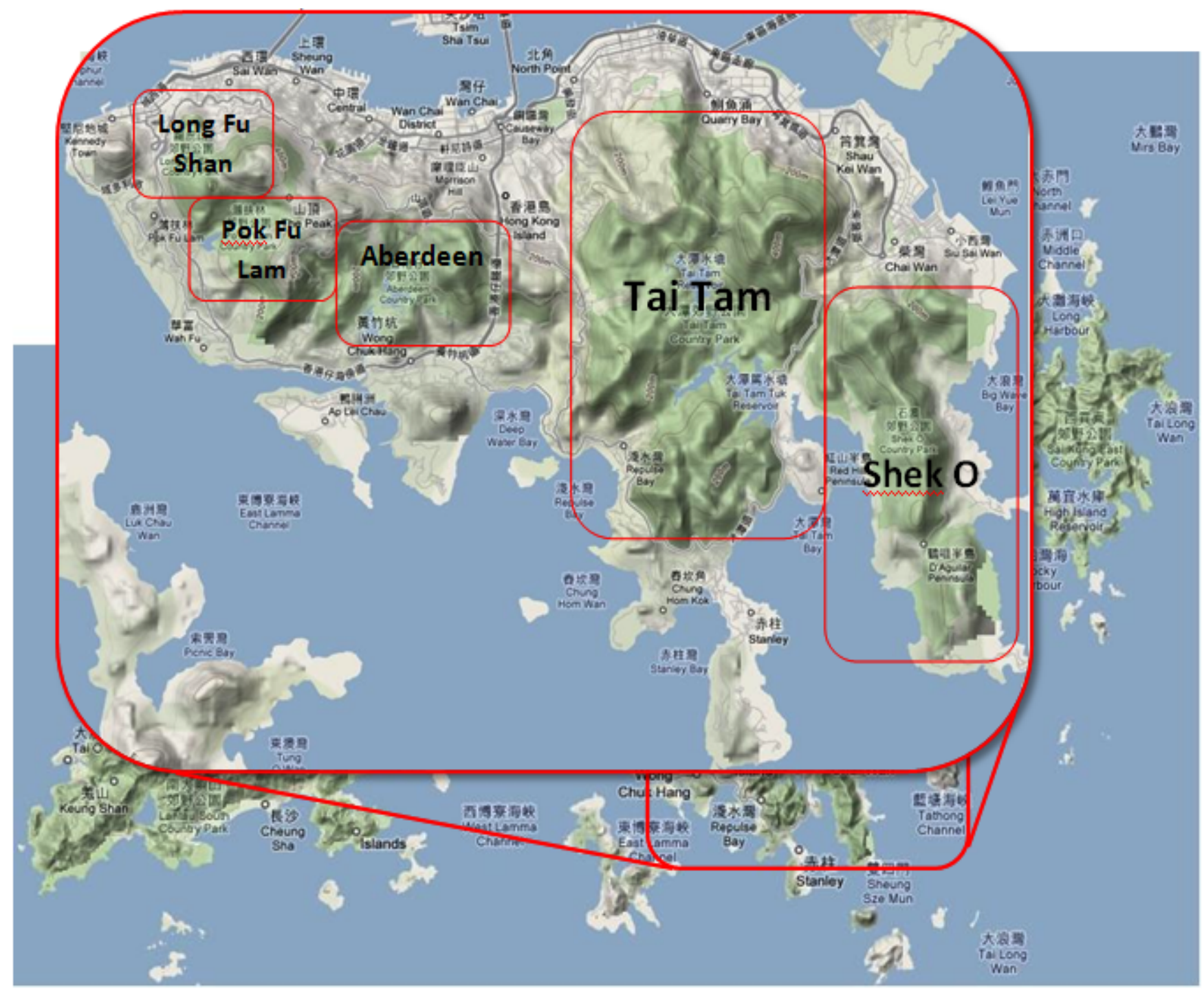

Captured from Google Maps.

Fig. (3). Country parks on Hong Kong Island. 
Table 3. Details of the Country Parks Located on Hong Kong Island

\begin{tabular}{|c|c|c|c|}
\hline $\begin{array}{c}\text { Country Park } \\
\text { (Year of Designation) }\end{array}$ & Park Size (ha) & Reservoir & Most Common Species \\
\hline $\begin{array}{l}\text { Shek O } \\
(1979)\end{array}$ & 702 & None & $\begin{array}{l}\text { Hong Kong Gordonia (Gordonia axillaris), Machilus } \\
\text { species, Ivy Tree (Schefflera heptaphylla), Aprorusa } \\
\text { (Aporusa dioica), Rose Myrtle (Rhodomyrtus tomentosa), } \\
\text { Buddhist Pine (Podocarpus macrophyllus), and Blue } \\
\text { Japanese Oak (Cycloblalanopsis glauca) }\end{array}$ \\
\hline $\begin{array}{l}\text { Tai Tam } \\
\text { (1977) }\end{array}$ & 1,315 & $\begin{array}{l}\text { Tai Tam Upper Reservoir, Tai Tam Byewash } \\
\text { Reservoir, Tai Tam Intermediate Reservoir } \\
\text { and Tai Tum Tuk Reservoir (Total storage } \\
\text { capacity: } 8.3 \text { million cubic meters }{ }^{11} \text { ) }\end{array}$ & $\begin{array}{l}\text { Taiwan Acacia (Acacia confuse) and Slash Pine (Pinus } \\
\text { elliottii) }\end{array}$ \\
\hline $\begin{array}{l}\text { Aberdeen } \\
(1977)\end{array}$ & 423 & $\begin{array}{l}\text { Aberdeen Upper Reservoir and Aberdeen } \\
\text { Lower Reservoir } \\
\text { (Total storage capacity: } 1.26 \text { million } \mathrm{m}^{3} \text { ) }\end{array}$ & $\begin{array}{l}\text { Brisbane Box (Lophostemon confertus), Schima (Schima } \\
\text { superb), Hong Kong Gordonia (Gordonia axillaris), and } \\
\text { Ivy Tree (Rhodomyrtus tomentosa) }\end{array}$ \\
\hline $\begin{array}{l}\text { Pok Fu Lam } \\
\text { (1979) }\end{array}$ & 270 & $\begin{array}{l}\text { Pok Fu Lam Reservoir } \\
\text { (Storage capacity: } 0.26 \mathrm{~m}^{3} \text { ) }\end{array}$ & $\begin{array}{l}\text { Introduced: Slash Pine (Pinus elliottii), Taiwan Acacia } \\
\text { (Acacia confuse), and Brisbane Box (Lophostemon } \\
\text { confertus) } \\
\text { Native: Hong Kong Gordonia (Gordonia axillaris) and } \\
\text { Chekiang Machilus (Machilus chekiangensis) } \\
\text { New plant species introduced during the government's } \\
\text { bio-diversity programme: Mountain Tallow Tree } \\
\text { (Sapium discolor), Water Machilus (Machilus oreophila), } \\
\text { Schima (Schima superba), Castanopsis (Castanopsis } \\
\text { fissa), Lingnan Garcinia (Garcinia oblongifolia), } \\
\text { Castanopsis fissa, Microcos (Microcos paniculata) and } \\
\text { Chinese Banyan (Ficus microcarpa) }\end{array}$ \\
\hline $\begin{array}{l}\text { Long Fu Shan } \\
\text { (1998) }\end{array}$ & 47 & None & $\begin{array}{l}\text { Brisbane Box (Lophostemon confertus), Hong Kong } \\
\text { Gordonia (Gordonia axillaris), Chekiang Machilus } \\
\text { (Machilus chekiangensis), and Ivy Tree (Rhodomyrtus } \\
\text { tomentosa) }\end{array}$ \\
\hline
\end{tabular}

low (Fig. 5). The marked increase in carbon sequestration in 1991 was due to the increased size of the woodland area as a result of natural succession since 1978. However, since the amount of carbon increased little after 1991, its carbon sequestration to area ratio was still only of $80.30 \mathrm{tC} \mathrm{ha}^{-1}$ in 2004.

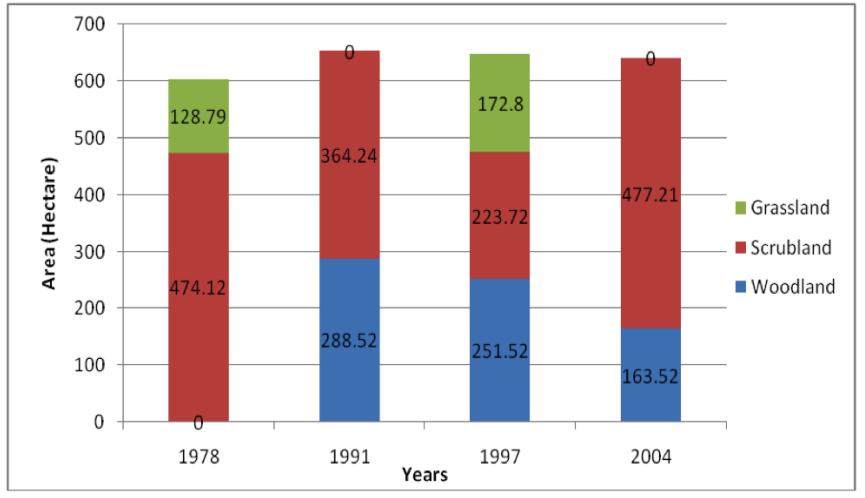

Fig. (4). Distribution of Vegetation in Shek O Country Park.

\section{Tai Tam Country Park}

Tai Tam Country Park abounds with woodland and scrubland. The park rarely has any form of landslide or hill fire, and neither does it have any significant sign of land

\footnotetext{
${ }^{11} 1$ cubic meter $\left(\mathrm{m}^{3}\right)=1000$ liters $=264.172052$ gallons
}

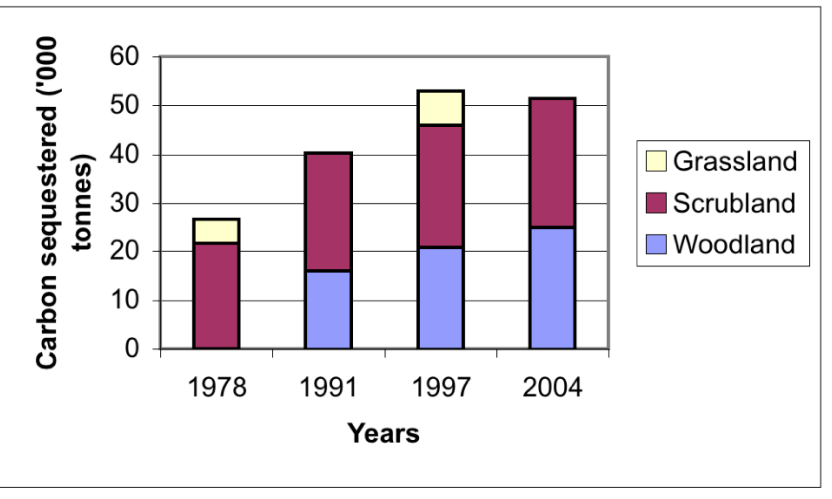

Fig. (5). Total amount of carbon sequestered in Shek O Country Park.

degradation or badlands (Fig. 6). The amount of woodlands in the park has grown each year, which is a sign of ecological evolution in which scrubland areas are replaced by woodland areas. The extra grassland and scrubland areas shown in 1997 indicates that some badland areas which appeared between 1991 and 1997 had been replenished by these two types of vegetation.

Fig. (7) shows that with the increasing amount of woodland area, the amount of carbon sequestered by woodlands grew from $49.84 \mathrm{tC} \mathrm{ha}^{-1}$ in 1978 to $102.32 \mathrm{tC} \mathrm{ha}^{-1}$ in 2004. It should be noted that these numbers may exaggerate the extent of sequestration, specially of 
woodlands, as the sequestration rate falls with the increasing age of the vegetation.

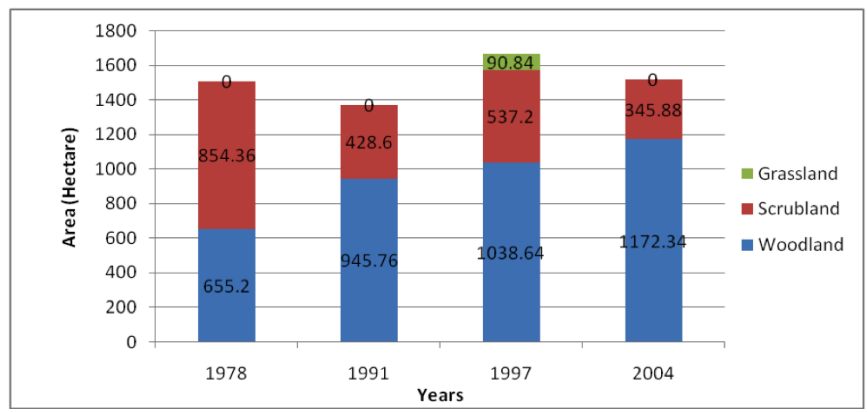

Fig. (6). Distribution of Vegetation in Tai Tam Country Park.

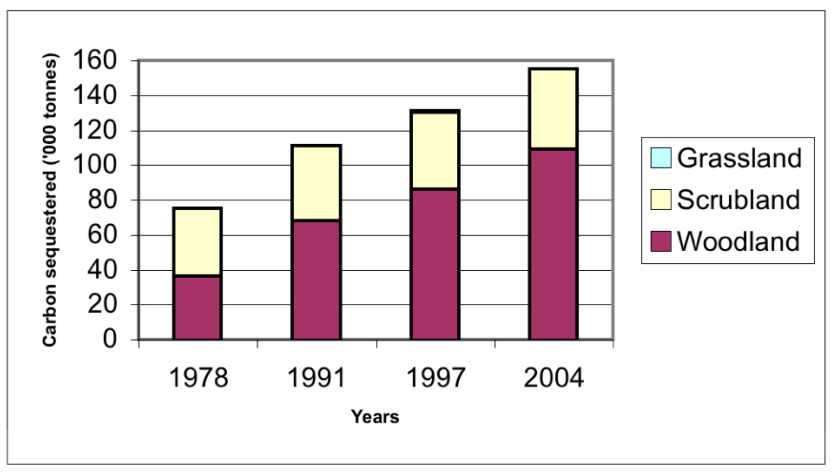

Fig. (7). Total amount of carbon sequestered in Tai Tam Country Park.

\section{Aberdeen and Pok Fu Lam Country Parks}

While images of Aberdeen Country Park for all four years investigated in this study were available, only images for the three latter years were available for Pok Fu Lam Country Park, which was established after 1978. In spit of this, there was a significant drop-off in the areas covered by vegetation in the two parks over the study period as the amount of badland areas and reservoirs rose (Fig. 8).

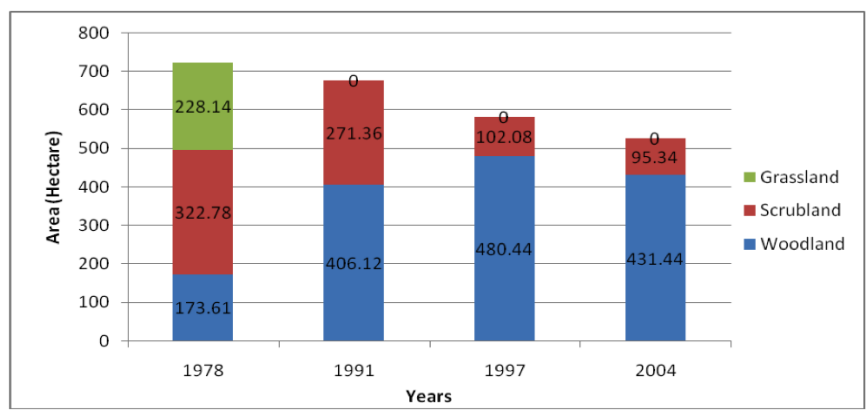

Fig. (8). Distribution of Vegetation in Aberdeen and Pok Fu Lam Country Parks.

In spite of the larger area taken up by badland and reservoirs after 1978, carbon sequestration in Aberdeen and Pok Fu Lam country parks increased, due to the increase in woodland areas and the combined effect of the two parks (Fig. 9). The amount of carbon stored in the vegetation and soil increased from $46.32 \mathrm{tC} \mathrm{ha}^{-1}$ in 1978 to $106.96 \mathrm{tC} \mathrm{ha}^{-1}$ in 2004.

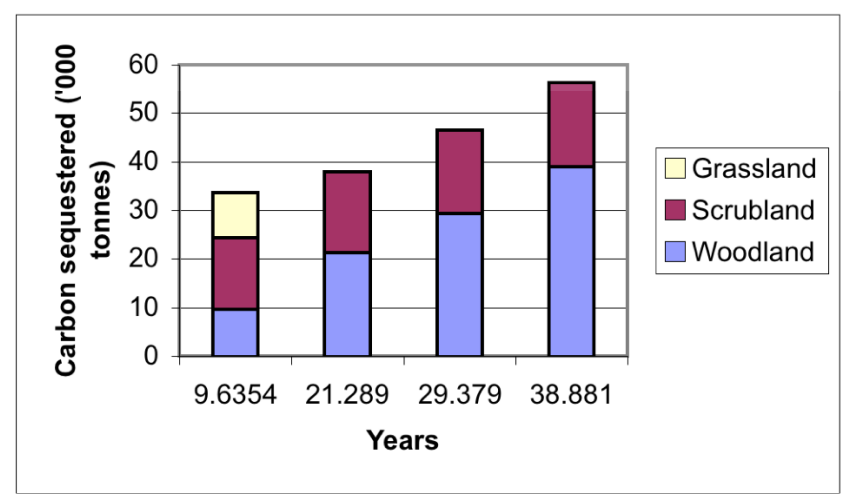

Fig. (9). Total amount of carbon sequestered in Aberdeen and Pok Fu Lam Country Parks.

\section{Long Fu Shan Country Park}

Long Fu Shan Country Park was established in 1998. The park consists of many bare soil/rock areas, most of which are likely to be the remnants of military structures built during the Second World War. In 1997 the park was about to be established and consequently lacked afforestation and conservation programs (Fig. 10). As would be expected, in 2004 the number of woodland and scrubland areas had increased.

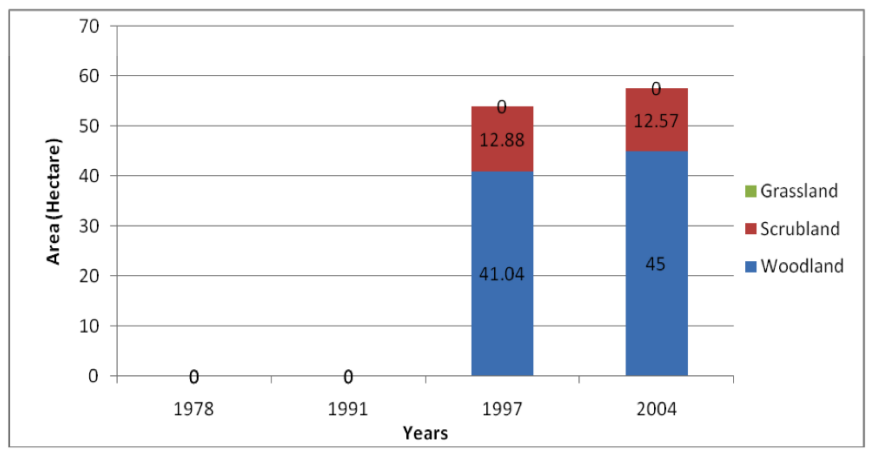

Fig. (10). Classification results for Long Fu Shan Country Park for 1997 and 2004.

Fig. (11) indicates the total amount of carbon sequestered in Long Fu Shan Country Park over the study period. It can be seen that the appearance of large woodland areas have led to an increase in the amount of carbon sequestered in the park. Nevertheless, the park had a carbon sequestration to area ratio of only $66.31 \mathrm{tC} \mathrm{ha}^{-1}$ in 2004 , the lowest of all Hong Kong country parks.

\section{Country Parks in the Sai Kung, Tseung Kwan O, Ma On} Shan, and Sha Tin Districts (Box B in Fig. 2)

Lion Rock, Ma On Shan, Clear Water Bay, Sai Kung West, Sai Kung East, and Sai Kung West (Wan Tsai ext.) country parks are spread across the Sai Kung, Tseung Kwan O, Ma On Shan, and Sha Tin districts (Fig. 12). Table 4 illustrates the size of each park, the existence of any reservoirs, and the major species present in each park.

\section{Lion Rock Country Park}

Lion Rock Country Park has a narrow mountain range stretching from east to west; the southern slopes are badly 


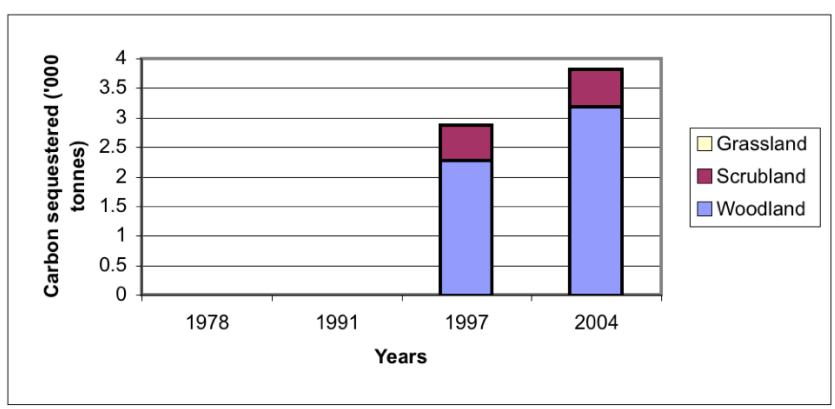

Fig. (11). Total amount of carbon sequestered in Long Fu Shan Country Park.

eroded and have only thin vegetation, whereas the northern slopes abound with vegetation. Therefore, the southern slopes often contain only scrublands or grasslands, although the amount of woodland increases nearer the feet of the mountains. As Fig. (13) shows, Lion Rock Country Park was badly eroded in 1978 and consisted mainly of scrubland and grassland areas. Most of the grasslands eventually became scrublands and turned into woodlands by 1991. However, hill fires and erosion led to the appearance of more badlands and the reappearance of grasslands in 1997, before the vegetation returned to its original woodland state as a result of natural succession, and the reforestation efforts of the Country Parks authorities.

Despite the severe effect of the erosion apparent in 1978, the country park was still able to contribute towards carbon sequestration (Fig. 14). In 2004, it had a carbon sequestration to area ratio of $79.29 \mathrm{tC} \mathrm{ha}^{-1}$.

\section{Ma On Shan Country Park}

Ma On Shan Country Park consists of a large number of bare soil/badland areas. This is because of its steep ridges and slopes, which make it inhospitable to many types of vegetation. Grasslands and scrublands are a common sight in Ma On Shan Country Park (Fig. 15), although the amount of woodlands increased every year except 2004, when a hill fire reduced woodland coverage.

In spite of its rugged terrain, Ma On Shan Country Park had a carbon sequestration to area ratio of $95.46 \mathrm{tC} \mathrm{ha}^{-1}$ in 2004 (Fig. 16).

\section{Clear Water Bay Country Park}

Clear Water Bay Country Park is composed mainly of scrubland and grassland, as the area is exposed to wind and has experienced constant erosion. The classification for the year 1991 is erroneous due to the poor quality of the satellite image, which prevented us from identifying as much woodland areas as there actually was at that time (Fig. 17). The year 1997 represents something of a low point in the park's topography due to the increase in badland areas, although there was also a degree of natural succession in areas that enjoyed increasing afforestation.

In the earlier part of the study period, Clear Water Bay Country Park was mainly covered by scrubland and grassland, as a result of which the amount of carbon sequestered in 1978 and 1991 was low (Fig. 18). However, as the natural succession process went on, the emergence of a lot more woodland was accompanied by an increase in carbon sequestration. In 2004, the park had a carbon

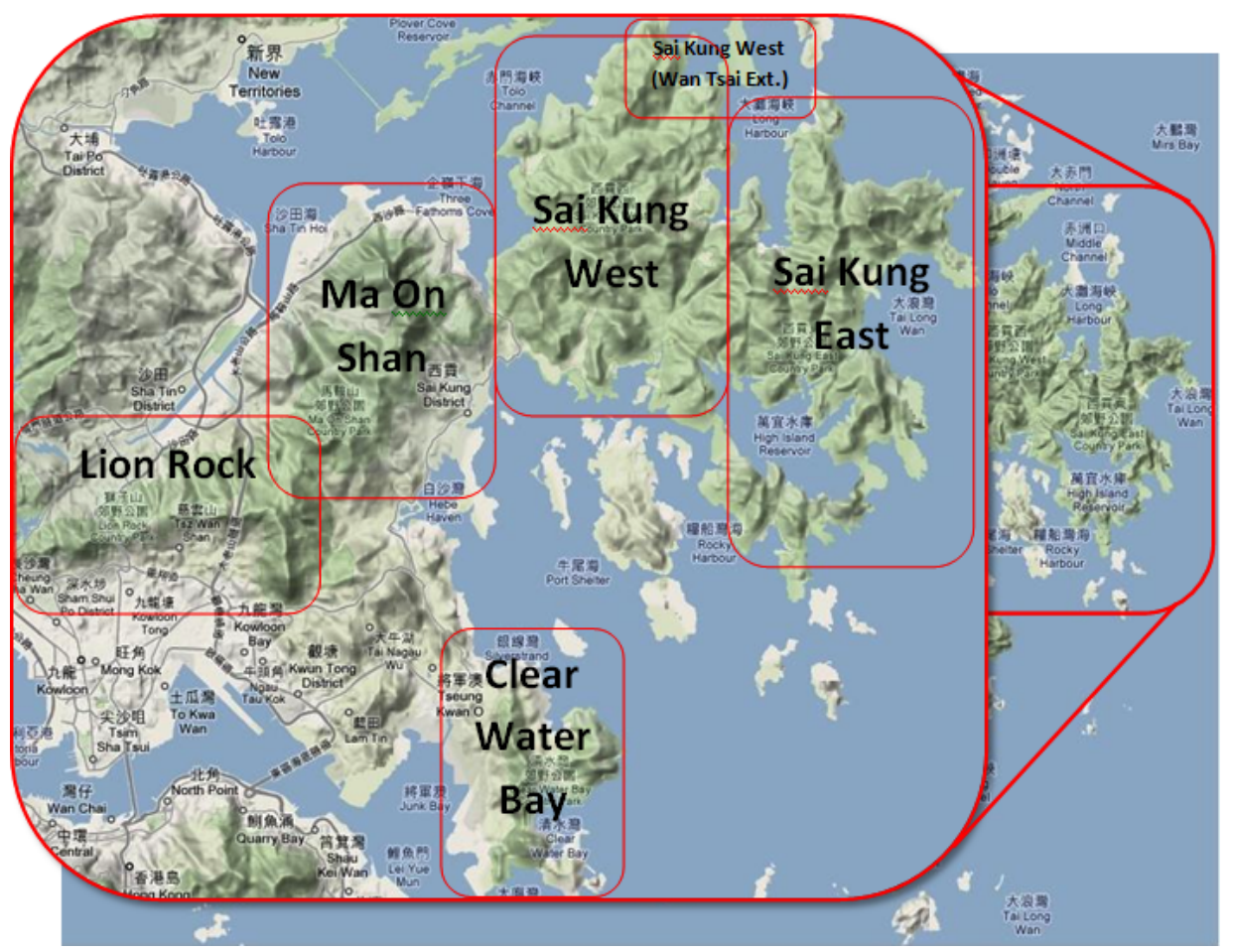

Source: Captured from Google Maps.

Fig. (12). Country Parks located in the Sai Kung, Tseung Kwan O, Ma On Shan, and Sha Tin Districts. 
Table 4. Details of the Country Parks Located in the Sai Kung, Tseung Kwan O, Ma On Shan, and Sha Tin Districts

\begin{tabular}{|c|c|c|c|}
\hline $\begin{array}{c}\text { Country Park (Year of } \\
\text { Designation) }\end{array}$ & Park Size (ha) & Reservoirs & Major Species (Most Common) \\
\hline $\begin{array}{l}\text { Lion Rock } \\
(1977)\end{array}$ & 557 & None & $\begin{array}{l}\text { Chinese Red Pine (Pinus massoniana), Strawberry Tree (Myrica rubra), } \\
\text { Chinese Hackberry (Celtis sinensis), Microcos (Microcos paniculata), } \\
\text { Fishpole Bamboo (Phyllostachys aurea), Incense Tree (Aquilaria sinensis), } \\
\text { Ivy Tree (Schefflera heptaphylla), Chinese New Year Flower (Enkianthus } \\
\text { quinqueflorus), and various Melastoma species. }\end{array}$ \\
\hline Ma On Shan (1979) & 2,880 & None & Sparse vegetation with no sign of trees. \\
\hline Clear Water Bay (1979) & 615 & None & $\begin{array}{l}\text { Incense Tree (Aquilaria sinensis), Ivy Tree (Schefflera heptaphylla), Lance- } \\
\text { leaved Sterculia (Sterculia lanceolata), Elephant's Ear (Macaranga tanarius), } \\
\text { Opposite-leaved Fig (Ficus hispida), Autumn Maple (Bischofia javanica), } \\
\text { Lingnan Garcinia (Garcinia oblongifolia), and pines trees. }\end{array}$ \\
\hline $\begin{array}{l}\text { Sai Kung West and Wan } \\
\text { Tsai Extension (1978) }\end{array}$ & 3,000 & None & $\begin{array}{l}\text { Native trees: Chinese Tallow Tree (Sapium sebiferum), Machilus species, } \\
\text { Fragrant Litsea (Litsea cubeba), Lance-leaved Sterculia (Sterculia lanceolata) } \\
\text { and Ivy Tree (Schefflera heptaphylla). } \\
\text { Plantation Species: Taiwan Acacia (Acacia confusa), Horsetail Tree } \\
\text { (Casuarina equisetifolia) and Slash Pine (Pinus elliottii) } \\
\text { Native shrubs: Myrobalan (Phyllanthus emblica), Rose Myrtle } \\
\text { (Rhodomyrtus tomentosa) and Dwarf Mountain Pine (Baeckea frutescens) } \\
\text { Afforestation species: Paper-bark Tree (Melaleuca quinquenervia), Brisbane } \\
\text { Box (Lophostemon confertus), Hong Kong Gordonia (Gordonia axillaris) and } \\
\text { Ivy Tree (Schefflera heptaphylla) }\end{array}$ \\
\hline Sai Kung East (1978) & 4,477 & $\begin{array}{l}\text { High Island } \\
\text { Reservoir (Storage } \\
\text { capacity: } 280 \text { million } \\
m^{3} \text { ) }\end{array}$ & $\begin{array}{l}\text { Dominant grassland plants: Minireed (Arundinella nepalensis), Duck-beak } \\
\text { Grass (Ischaemum aristatum glaucum) and Linear Forked Fern } \\
\text { (Dicranopteris linearis). } \\
\text { Shrublands: Common Melastoma (Melastoma candidum), Rose Myrtle } \\
\text { (Rhodomyrtus tomentosa), Dwarf Mountain Pine (Baeckea frutescens), } \\
\text { Shining Eurya (Eurya nitida) and Hong Kong Gordonia (Gordonia axillaris) }\end{array}$ \\
\hline
\end{tabular}

Sources: AFCD [13]; WSD [30].

sequestration to area ratio of $66.31 \mathrm{tC} \mathrm{ha}^{-1}$, an improvement owing to a landscape by now dominated by scrublands and grasslands.

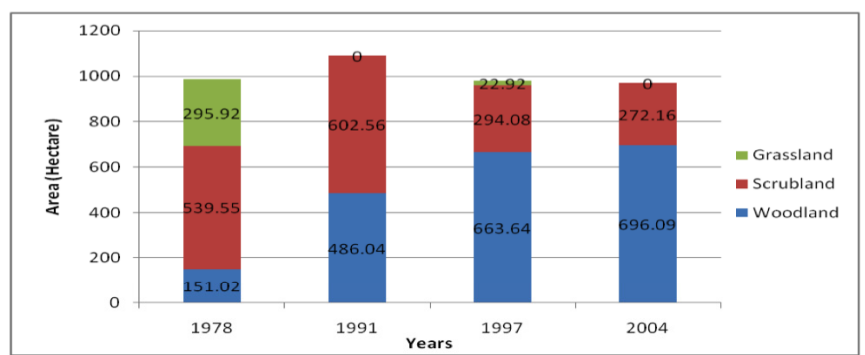

Fig. (13). Distribution of Vegetation in Lion Rock Country Park.

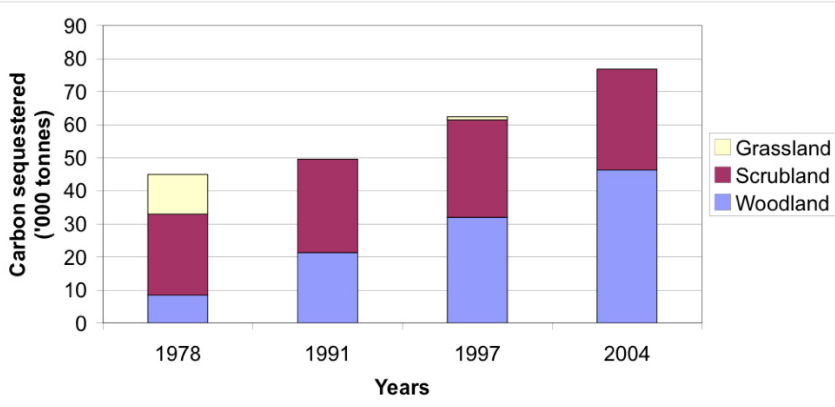

Fig. (14). Total amount of carbon sequestered in Lion Rock Country Park.

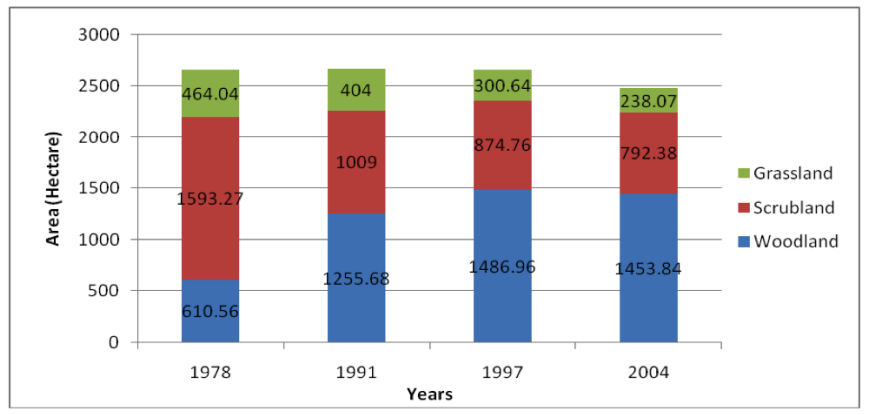

Fig. (15). Classification results for Ma On Shan Country Park for the years 1978, 1991, 1997, and 2004.

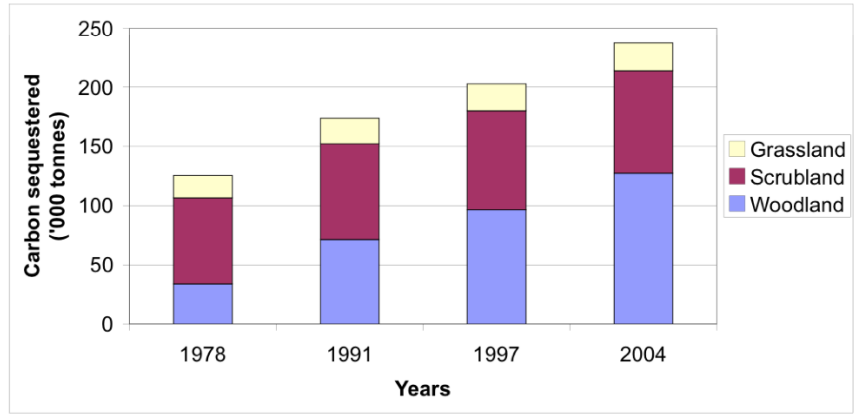

Fig. (16). Total amount of carbon sequestered in Ma On Shan Country Park. 


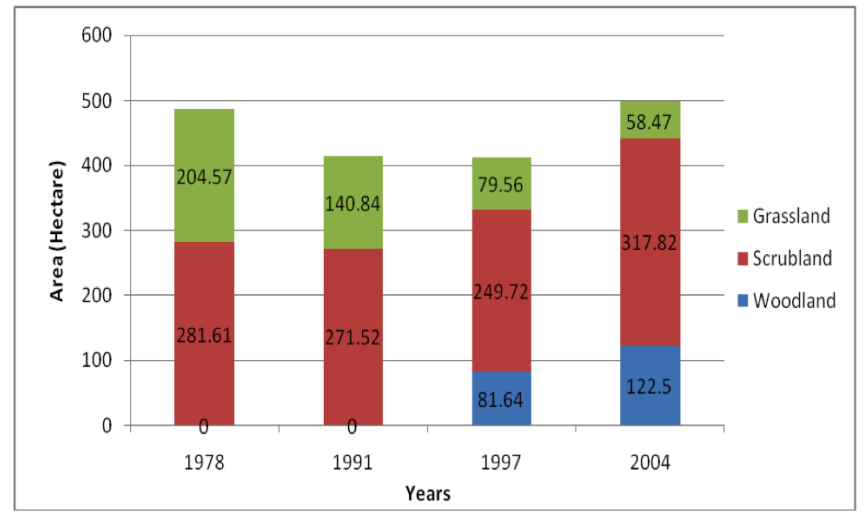

Fig. (17). Distribution of Vegetation in Clear Water Bay Country Park.

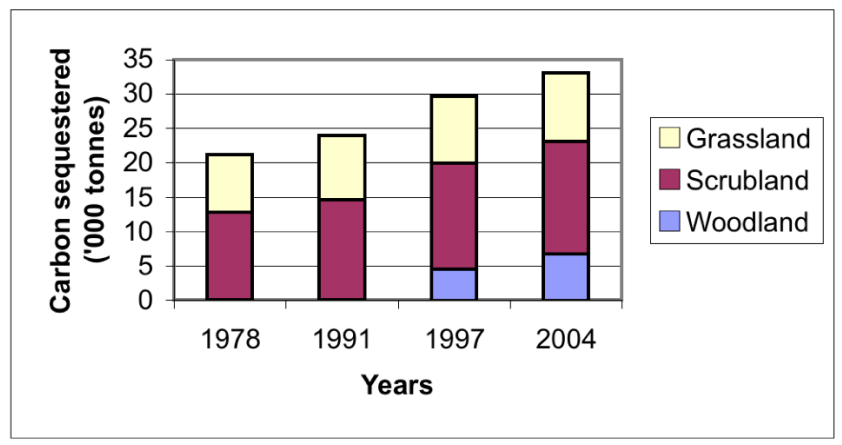

Fig. (18). Total amount of carbon sequestered in Clear Water Bay Country Park.

\section{Sai Kung Country Park}

Sai Kung Country Park, which is dominated by woodland and scrubland areas, rarely suffers from anthropogenic disturbances; this has allowed woodland areas to cover most of the park due to the process of natural succession. The appearance of grasslands in 1978 (Fig. 19) was due to the emergence of several badland areas. In these areas, grasses dominated, as no scrub or trees provided protection from the sunlight. In time, natural succession resulted in the disappearance of most of the grasslands. The amount of woodland observed in each year for which images were studied stayed basically the same. The sudden drop-off in woodland coverage in 2004 was due to an increase in rocky or bare soil areas.

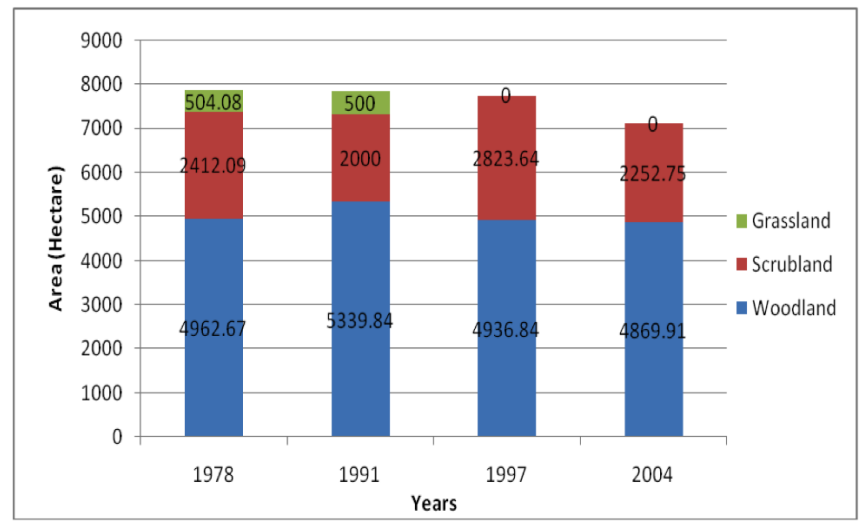

Fig. (19). Distribution of Vegetation in Sai Kung Country Park.
The amount of carbon sequestered in the park came mainly from woodland areas. In 2004, the park had a carbon sequestration to area ratio of $113.98 \mathrm{tC} \mathrm{ha}^{-1}$ (Fig. 20).

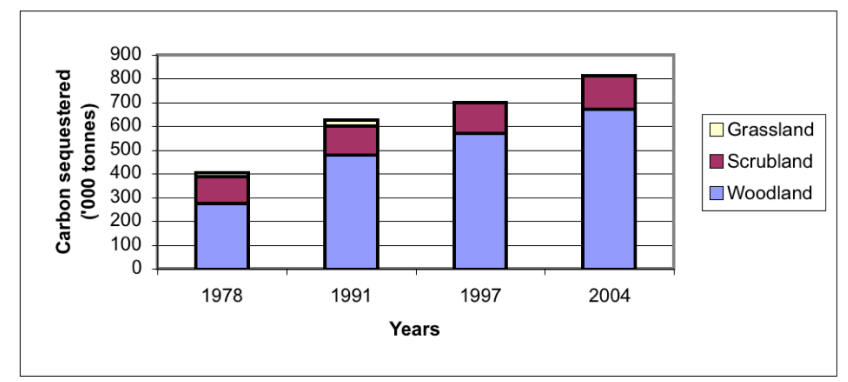

Fig. (20). Total amount of carbon sequestered in Sai Kung Country Park.

Country Parks in the Yuen Long, Tsuen Wan, and Sha Tin Districts (Box C in Fig. 2)

Lam Tseun, Tai Lam, Tai Mo Shan, and Kam Shan country parks are located in the Yuen Long, Tsuen Wan, and Sha Tin districts (as shown in Fig. 21). Table 5 illustrates the size of each park, the existence of any reservoirs, and the major species present in each park.

\section{Lam Tsuen Country Park}

Lam Tsuen Country Park suffers from extreme erosion on the southern slopes of its northernmost mountain, which is predominantly grasslands and scrublands. In contrast, the northern part of each mountain in the park abounds with woodlands and scrublands. The natural succession process is rarely a feature of this park due to its unstable terrain (Fig. 22). However, it can be seen that there was an increase in woodland areas in 2004, probably because of better management and/or fewer landslides and hill fires.

The park had a carbon sequestration to area ratio of 78.98 $\mathrm{tC} \mathrm{ha}^{-1}$ in 2004; the reason for this relatively low ratio was the poor condition of its southern slopes (Fig. 23).

\section{Tai Lam Country Park}

Tai Lam Country Park consists mainly of granite, which is highly vulnerable to erosion and land degradation. The majority of the park is either covered with bare soil or badland (Fig. 24). Nevertheless, the woodland areas of Tai Lam Country Park, which is the second largest country park in Hong Kong, are extensive. Grassland areas have receded over time. The sudden drop-off in grassland areas in 1991 was due to an increase in badland or bare soil areas.

Most of the carbon sequestered in Tai Lam Country Park is stored in its woodland areas (Fig. 25). The park had a carbon sequestration to area ratio of only $91.73 \mathrm{tC} \mathrm{ha}^{-1}$ in 2004 as a result of the severe erosion that has plagued the park.

\section{Tai Mo Shan Country Park}

It is no surprise that Tai Mo Shan Country Park, which includes the tallest mountain in Hong Kong, has a high proportion of bare soils and badlands. The steep slopes and rugged terrain of the park discourage thick vegetation. The large area of bare soil contained by the park is evident from 


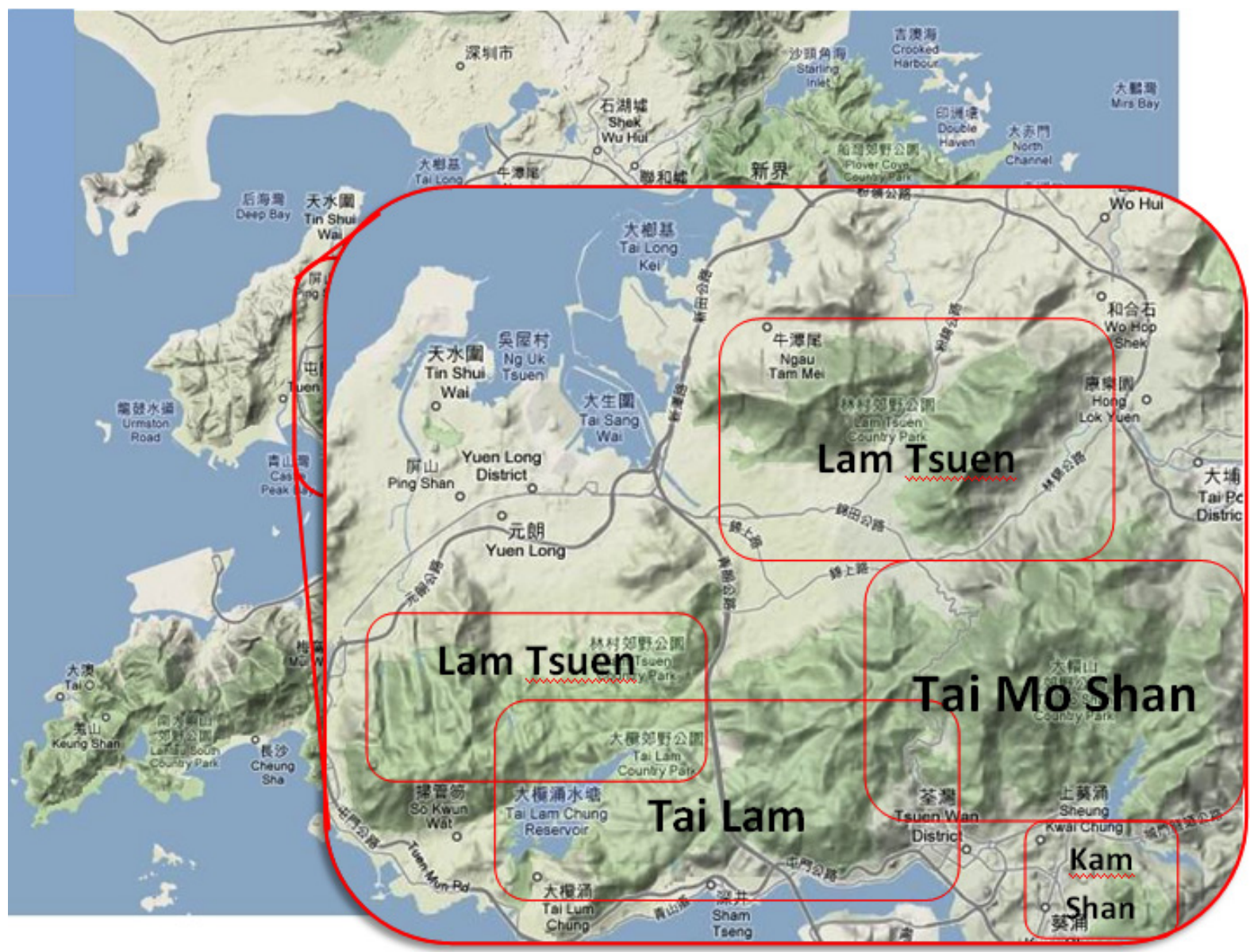

Captured from Google Maps.

Fig. (21). Country Parks located in the Yuen Long, Tsuen Wan, and Sha Tin Districts.

Table 5. Details of the Country Parks located in the Yuen Long, Tsuen Wan, and Sha Tin Districts

\begin{tabular}{|c|c|c|c|}
\hline Country Park (Year of Designation) & Park Size (ha) & Reservoirs & Major Species (Most Common) \\
\hline $\begin{array}{l}\text { Lam Tsuen } \\
\text { (1979) }\end{array}$ & 1,520 & $\begin{array}{l}\text { Lam Tai Reservoir, Hung } \\
\text { Shui Reservoir, Wong Nai } \\
\text { Tun Reservoir }\end{array}$ & $\begin{array}{l}\text { Pastoral Plantations: Machilus species, Taiwan Acacia } \\
\text { (Acacia confusa) and Brisbane Box (Lophostemon } \\
\text { confertus) }\end{array}$ \\
\hline $\begin{array}{l}\text { Tai Lam } \\
\text { (1979) }\end{array}$ & 5,370 & $\begin{array}{l}\text { Tai Lam Chung Reservoir } \\
\text { (Storage capacity: } 20 \\
\text { million } \mathrm{m}^{3} \text { ) }\end{array}$ & $\begin{array}{l}\text { Taiwan Acacia (Acacia confusa), Brisbane Box } \\
\text { (Lophostemon confertus), Chinese Red Pine (Pinus } \\
\text { massoniana), Slash Pine (Pinus elliottii) and Swamp } \\
\text { Mahogany (Eucalyptus robusta) } \\
\text { Native Trees: Oak and Machilus species and Castanopsis } \\
\text { (Castanopsis fissa) }\end{array}$ \\
\hline $\begin{array}{l}\text { Tai Mo Shan } \\
\text { (1979) }\end{array}$ & 1,440 & $\begin{array}{l}\text { Shing Mun Reservoir } \\
(\text { Storage capacity: } 17.58 \\
\text { million } \mathrm{m}^{3} \text { ) }\end{array}$ & $\begin{array}{l}\text { Plantations are found in the southeastern part of the park. } \\
\text { Upper slopes are vegetated mainly by shrubs and grass }\end{array}$ \\
\hline $\begin{array}{l}\text { Kam Shan } \\
(1977)\end{array}$ & 337 & $\begin{array}{l}\text { Kowloon Reservoir, Shek } \\
\text { Lei Pui Reservoir, Kowloon } \\
\text { Reception Reservoir, and } \\
\text { Kowloon Byewash } \\
\text { Reservoir } \\
\text { (Total storage capacity: } 2.9 \\
\text { million } \mathrm{m}^{3} \text { ) }\end{array}$ & $\begin{array}{l}\text { Melastoma species, Rose Myrtle (Rhodomyrtus tomentosa), } \\
\text { Acronychia (Acronychia pedunculata), Hong Kong } \\
\text { Gordonia (Gordonia axillaris), Fragrant Litsea (Litsea } \\
\text { cubeba), Red Machilus (Machilus thunbergii), Pop-gun } \\
\text { Seed (Bridelia tomentosa) and Ivy Tree (Schefflera } \\
\text { heptaphylla), and the rather special Ram-rod Bamboo } \\
\text { (Arundinaria hindsii) }\end{array}$ \\
\hline
\end{tabular}

Fig. (26), which highlight the fact that badlands and bare soil predominate here. The severity of the situation can be seen in the 1997 image, which shows a combination of bare soil and hill-fire affected areas, revealing a dramatic drop-off in vegetation. The subsequent increase in the number of woodland areas indicates that afforestation programs and other programs may have been implemented to replenish the affected areas. 


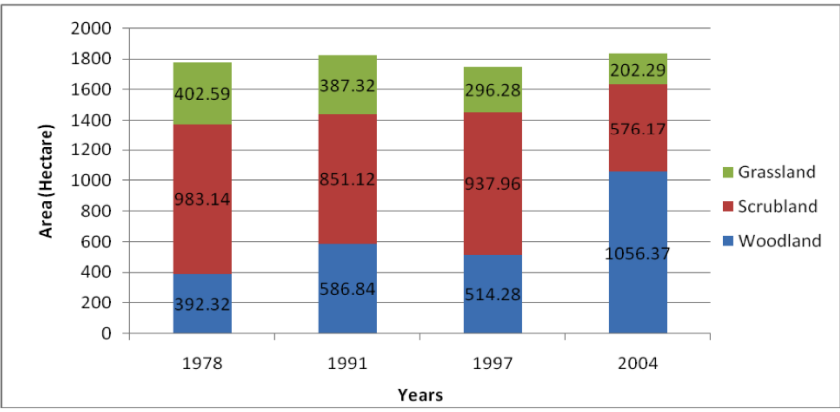

Fig. (22). Distribution of Vegetation in Lam Tsuen Country Park.

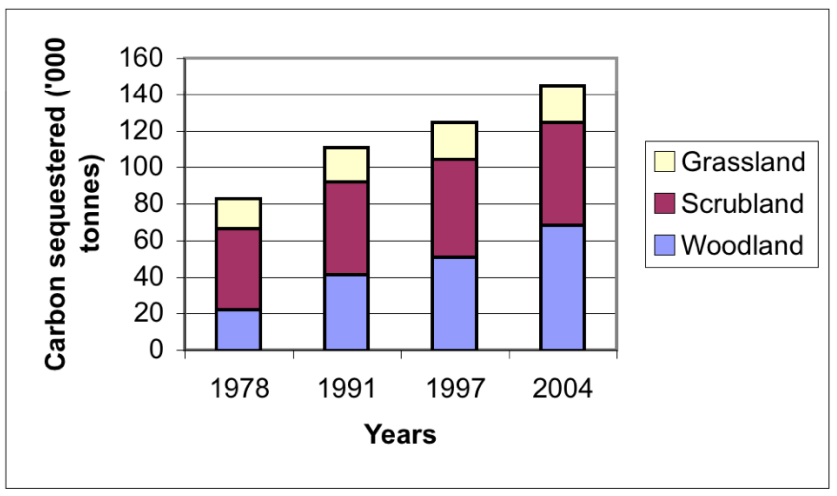

Fig. (23). Total amount of carbon sequestered in Lam Tsuen Country Park.

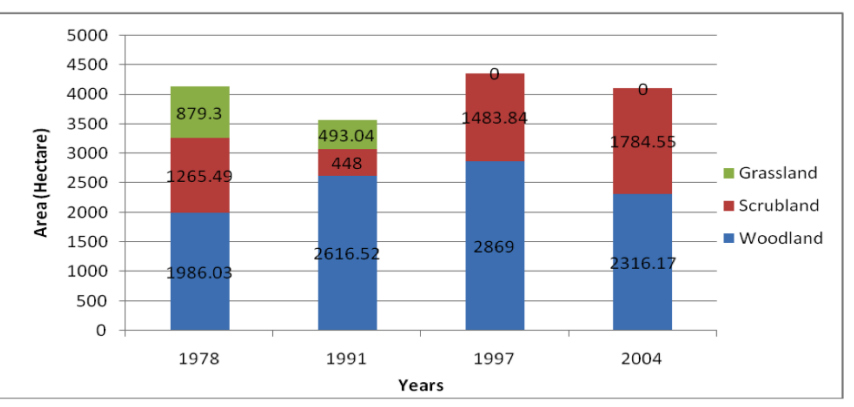

Fig. (24). Distribution of Vegetation in Tai Lam Country Park.

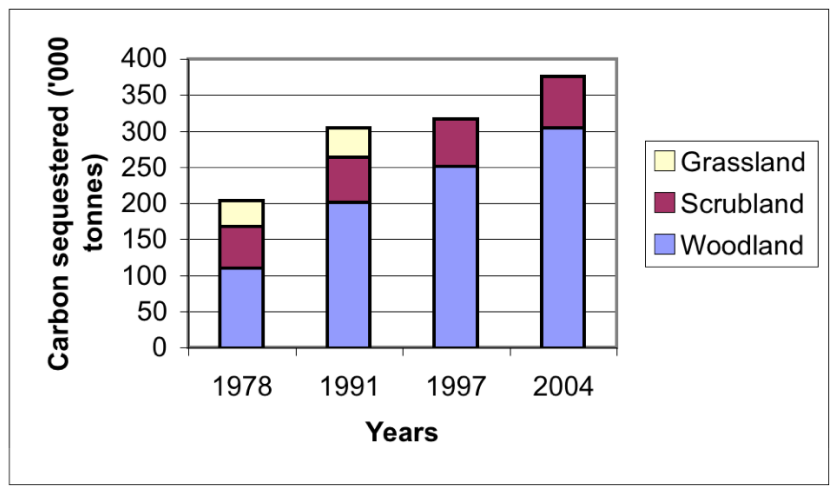

Fig. (25). Total amount of carbon sequestered in Tai Lam Country Park.

Due to Tai Mo Shan Country Park's rough terrain, not a lot of additional carbon was sequestered from 1991 to 2004 (Fig. 27), and 2004 the amount of carbon sequestered in the park was of only $71.93 \mathrm{tC} \mathrm{ha}^{-1}$. It should be reminded that in these estimates we consider the non-vegetated areas as having no carbon, which of course is not entirely correct since the soil still contains carbon.

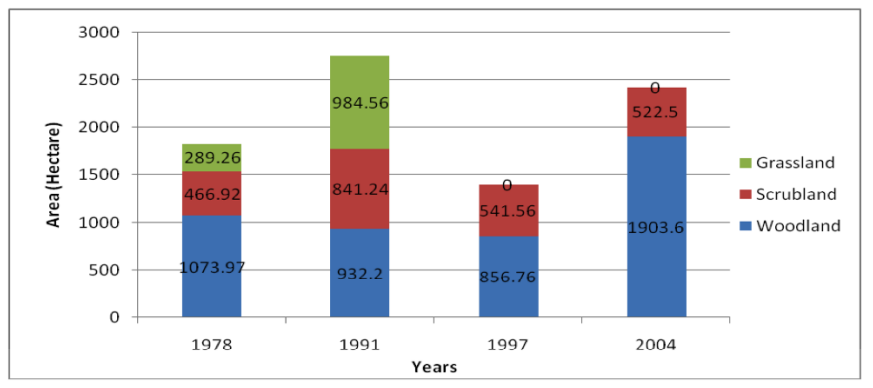

Fig. (26). Distribution of Vegetation in Tai Mo Shan Country Park.

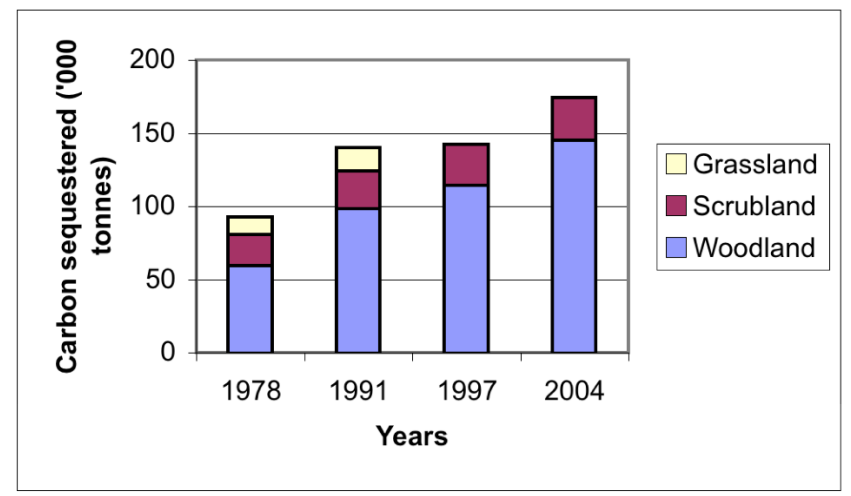

Fig. (27). Total amount of carbon sequestered in Tai Mo Shan Country Park.

\section{Kam Shan Country Park}

Although Kam Shan Country Park is smaller than Hong Kong's other country parks, it incorporates many woodland areas. One reason for this is that it is located in a lush and fertile reservoir catchment area. The drop-off in woodland areas between 1997 and 2004 was due to an increase in erosion (Fig. 28).

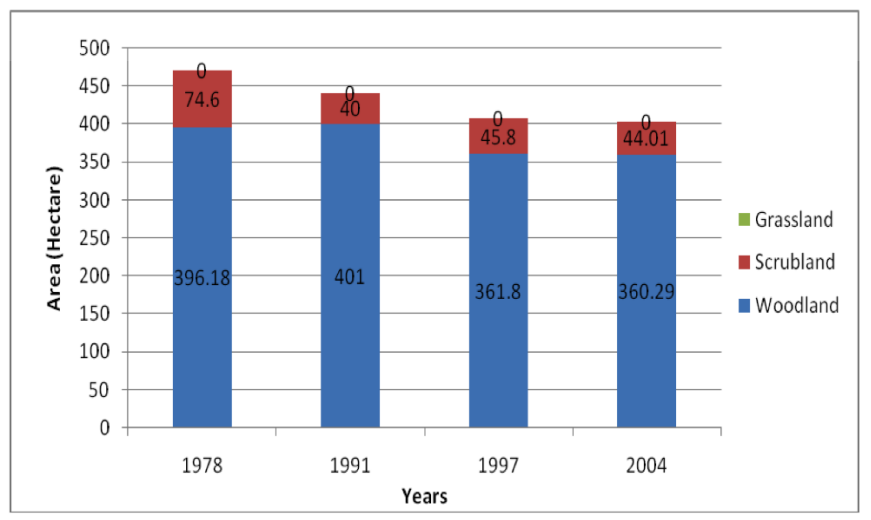

Fig. (28). Areal distribution of Kam Shan Country Park.

\section{Country Parks in the Tai Po and Plover Cove Districts (Box D in Fig. 2)}

Pat Sin Leng and Plover Cove Country Parks are located in the Tai Po and Plover Cove districts, respectively (Fig. 30). Table 6 illustrates the size of each park, the existence of any reservoirs, and the major species present in each park. 


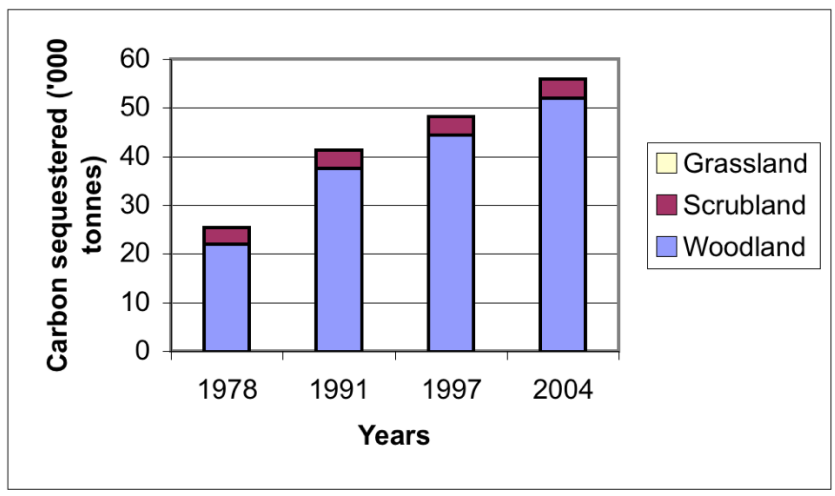

Fig. (29). Total amount of carbon sequestered in Kam Shan Country Park.

\section{Pat Sin Leng Country Park}

Pat Sin Leng Country Park is infamous for one of the deadliest hill fires to have hit Hong Kong, which claimed the lives of a dozen secondary school students and several teachers. The park is highly prone to hill fires and has seen fluctuations in the types of vegetation that have grown there over the years (Fig. 31). The 1991 and 2004 images are examples of years with visible effects of hill fires, with a sudden increase in grasslands and less scrublands and woodlands.

Since Kam Shan Country Park abounds in woodland areas, it sequestrates a rather large amount of carbon (Fig. 29). In $2004,138.44 \mathrm{tC} \mathrm{ha}^{-1}$ were sequestered.

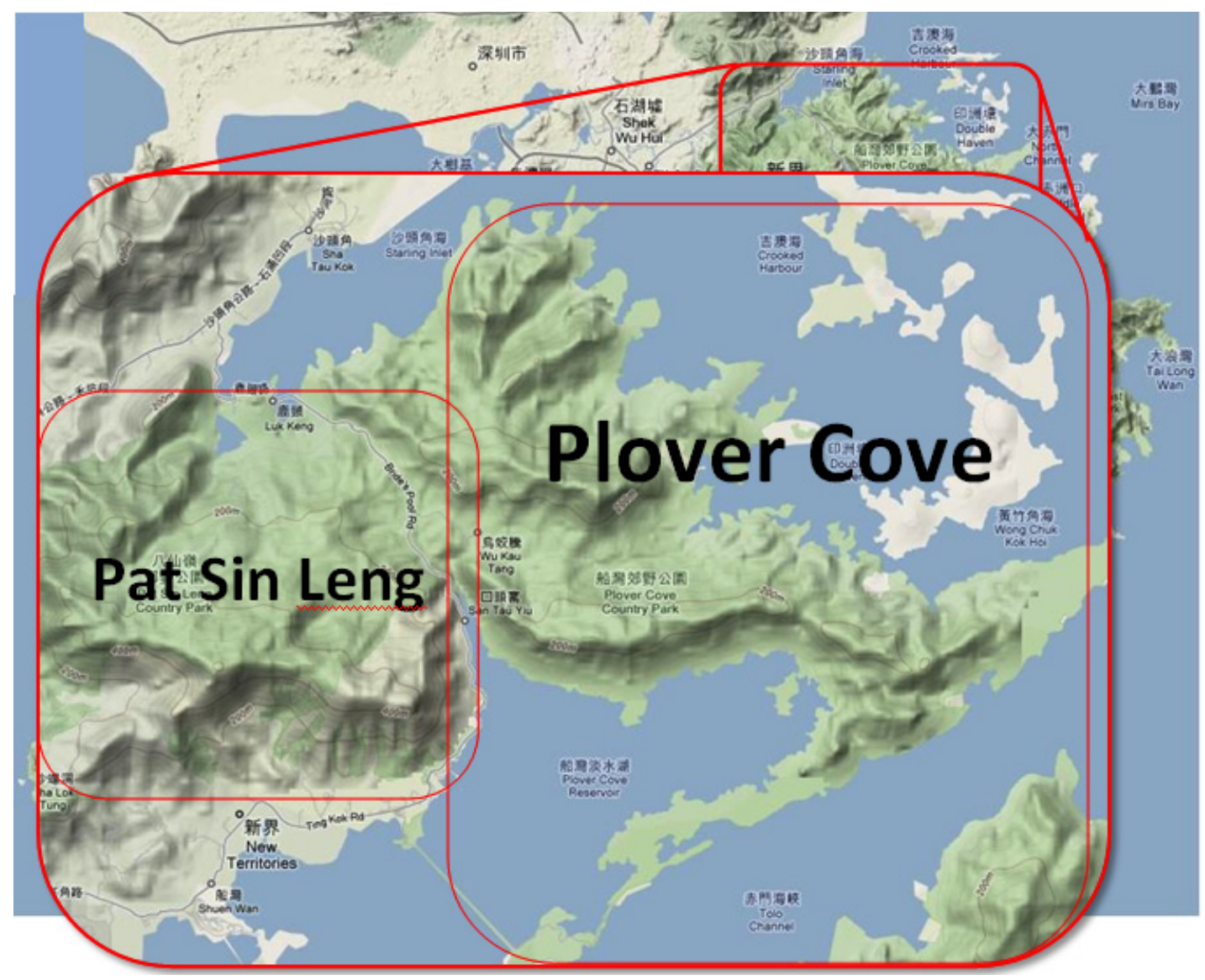

Captured from Google Maps.

Fig. (30). Country Parks in the Tai Po and Plover Cove Districts.

Table 6. Details of the Country Parks Located in the Tai Po and Plover Cove Districts

\begin{tabular}{|l|l|l|l|}
\hline Country Park (Year of Designation) & Park Size (ha) & Reservoirs & Major Species (Most Common) \\
\hline \hline $\begin{array}{l}\text { Pat Sin Leng } \\
(\mathbf{1 9 7 8 )}\end{array}$ & 3,125 & Hok Tau Reservoir and Lau Shui Heung Reservoir & Plantations and wooded valleys \\
\hline $\begin{array}{l}\text { Plover Cove } \\
(\mathbf{1 9 7 8 )}\end{array}$ & 4,594 & $\begin{array}{l}\text { Plover Cove Reservoir } \\
\text { (Storage capacity: } 230 \text { million }^{3} \text { ) } \\
\text { (Area: } 24 \text { ha) }\end{array}$ & $\mathrm{n} / \mathrm{a}$ \\
\hline
\end{tabular}




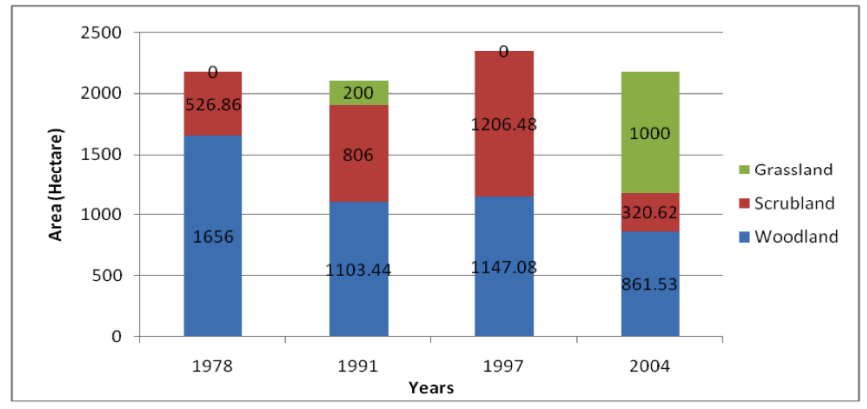

Fig. (31). Distribution of Vegetation in Pat Sin Leng Country Park.

In spite of the vegetation composition of the Pat Sin Leng Country Park fluctuating during the study period, the amount of carbon sequestered in the park increased from $53.09 \mathrm{tC} \mathrm{ha}^{-1}$ in 1978 to $119.29 \mathrm{tC} \mathrm{ha}^{-1}$ in 2004 (Fig. 32).

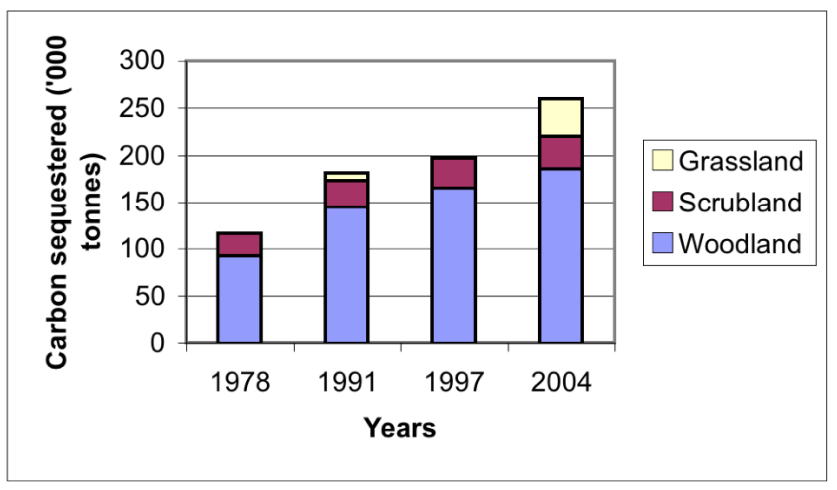

Fig. (32). Total amount of carbon sequestered in Pat Sin Leng Country Park.

\section{Plover Cove Country Park}

Plover Cove Country Park consists mainly of woodlands, although on the southern facing slopes, bare soils and grassland areas predominate. While Fig. (33) indicates that grasslands were a prominent feature of the park only in 1991 and 1997, it is likely that the park also hosted grasslands in the other years. The relevant data were probably lost due to the limitations in the quality of the satellite images used.

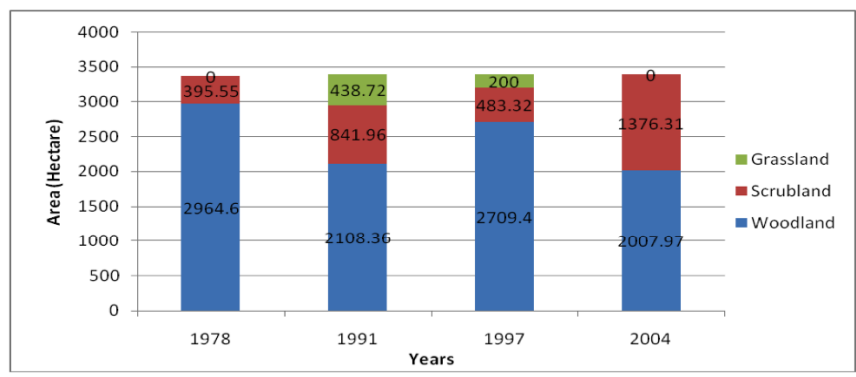

Fig. (33). Areal distribution of Plover Cove Country Park.

Due to the fluctuating proportion of grassland and scrubland areas in the park, the amount of carbon sequestered increased slowly from 1991(Fig. 34). Greater carbon sequestration took place in the years in which woodlands covered more of the park, which had a carbon sequestration to area ratio of $113.00 \mathrm{tC} \mathrm{ha}^{-1}$ in 2004 .

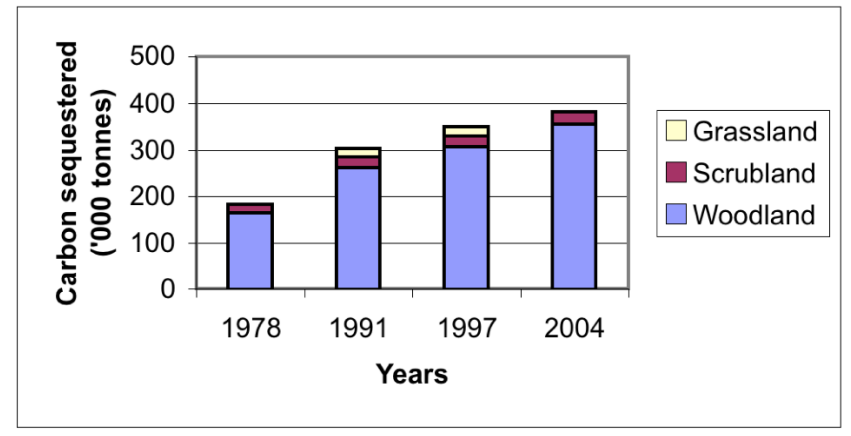

Fig. (34). Total amount of carbon sequestered in Plover Cove Country Park.

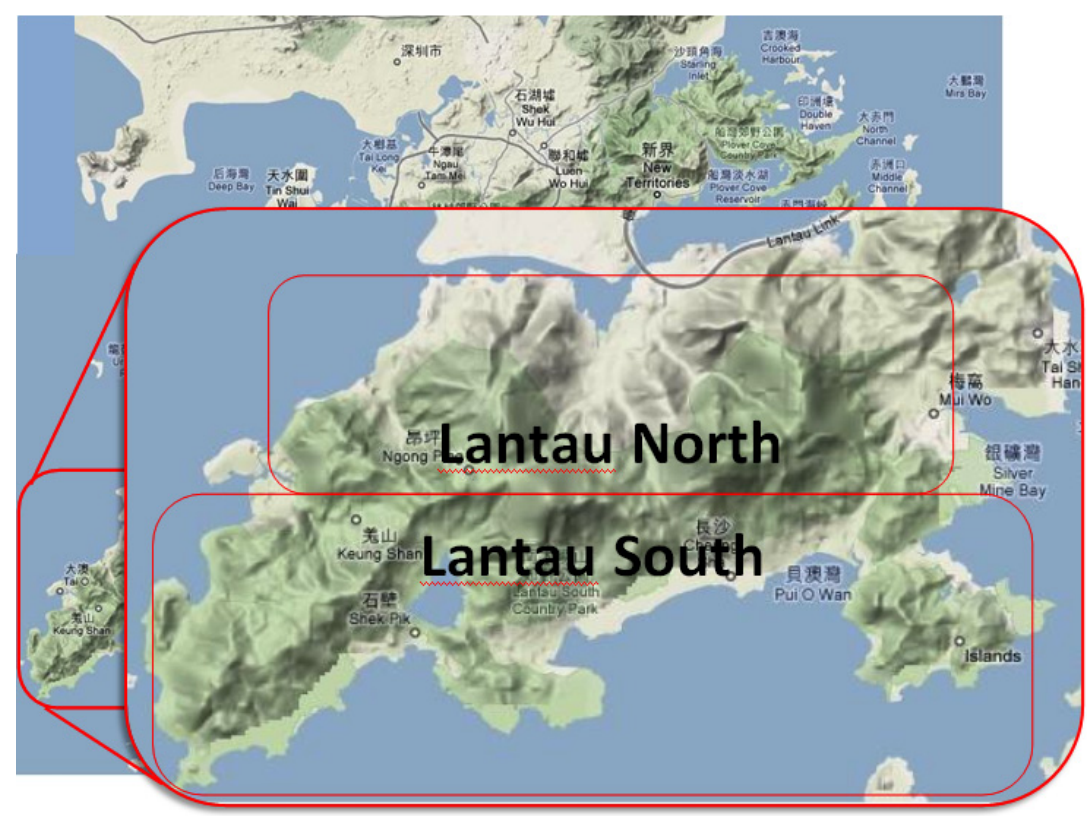

Captured from Google Maps.

Fig. (35). Country Parks on Lantau Island. 
Table 7. Details of the Country Parks Located on Lantau Island

\begin{tabular}{|l|l|l|l|}
\hline Country Park (Year of Designation) & Park Size (ha) & Reservoirs & Major Species (Most Common) \\
\hline \hline $\begin{array}{l}\text { Lantau North } \\
\mathbf{( 1 9 7 8 )}\end{array}$ & 2,200 & None & $\begin{array}{l}\text { Hong Kong Gordonia (Gordonia axillaris), Rhododendrons and Azaleas, } \\
\text { Orchids, Schima (Schima superba), Chinese Alangium (Alangium chinense), } \\
\text { Wax Tree (Rhus succedanea), Uvaria (Uvaria macrophylla) and Hong Kong } \\
\text { Asarum (Asarum hongkongense) }\end{array}$ \\
\hline $\begin{array}{l}\text { Lantau South } \\
(\mathbf{1 9 7 8 )}\end{array}$ & 14,400 & $\begin{array}{l}\text { Shek Pik } \\
\text { Reservoir } \\
\text { (Storage } \\
\text { capacity: } 24 \\
\left.\text { million } \text { m }^{3}\right)\end{array}$ & $\begin{array}{l}\text { Secondary forests: Tree Ginseng (Dendropanax dentigerus), Hong Kong } \\
\text { Magnolia (Magnolia championii) and Gmelina chinensis }- \text { listed in } \\
\text { Illustration of Rare and Endangered Plants in Guangdong Province. } \\
\text { Early afforestation species: Taiwan Acacia (Acacia confusa), Brisbane Box } \\
\text { (Lophostemon confertus) and Slash Pine (Pinus elliottii) } \\
\text { Native Plants: Chinese Hackberry (Celtis sinensis), Fragrant Litsea (Litsea } \\
\text { cubeba), Lidded Cleistocalyx (Cleistocalyx operculatus), Camphor Tree } \\
\text { (Cinnamomum camphora), Reevesia (Reevesia thyrsoidea), Chinese Banyan } \\
\text { (Ficus microcarpa) and Strawberry Tree (Myrica rubra) }\end{array}$ \\
\hline
\end{tabular}

Sources: AFCD [13]; WSD [30].

\section{Country Parks on Lantau Island (Box E in Fig. 2)}

Lantau North and Lantau South country parks are located on Lantau Island (Fig. 35). Table 7 illustrates the size of each park, the existence of any reservoirs, and the major species present in each park.

\section{Lantau South and Lantau North Country Parks}

The two country parks on Lantau Island (which are often referred to together as Lantau Country Park) cover about two-thirds of the island. They feature different types of terrain and abound in woodlands. The satellite images show that grassland and scrubland areas have receded after 1991 (Fig. 36).

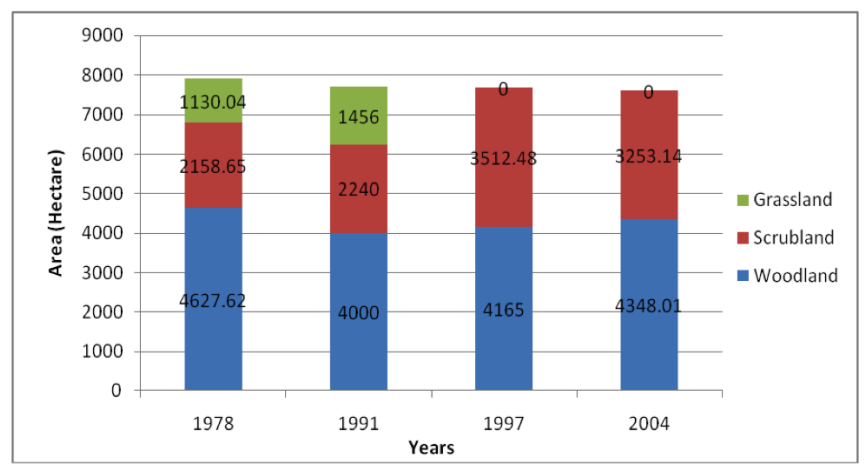

Fig. (36). Distribution of Vegetation in Lantau Country Park.

The amount of carbon sequestered in the park has stayed relatively constant each year, as the amount of woodlands has remained largely unchanged (Fig. 37). The combined vegetations and soils had a carbon sequestration ratio of $94.83 \mathrm{tC} \mathrm{ha}^{-1}$ in 2004.

\section{CONCLUSIONS AND DISCUSSION}

The carbon sequestration data used in our study show large variations across Hong Kong's country parks. These large variations among the parks can be explained by differences in elevation, slope gradients, and the incidence of wild fires, among other factors. The values shown in this study do not include the carbon sequestered by the water bodies in each park. One of the purposes of establishing the country park system was to provide watershed services, and the establishment of country parks in the late 1970s was accompanied by the construction of two very large reservoirs, the Sai Kung East reservoir (storage capacity: 280 million $\mathrm{m}^{3}$, see Table 4) and the Plover Cove reservoir (storage capacity: 230 million $\mathrm{m}^{3}$, see Table 6). The carbon stored in these two reservoirs was not included in this analysis, but the two reservoirs combined can hold up to 584.3 million $\mathrm{m}^{3}$ of water. If the carbon content of these reservoirs were to be included, the total amount of carbon sequestered from the atmosphere by the country parks would be higher.

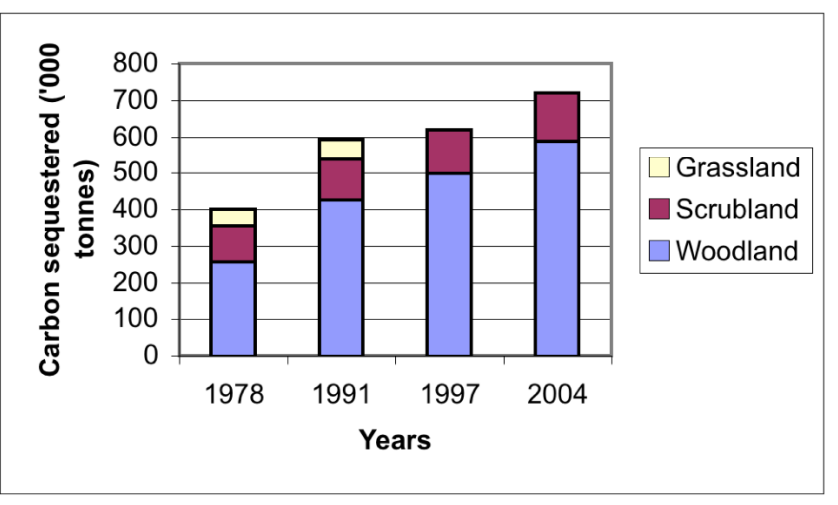

Fig. (37). Total amount of carbon sequestered in Lantau Country Park.

Fig. (38) shows changes in the distribution of vegetation in Hong Kong's country parks in 1978, 1991, 1997, and 2004. The figure indicates that there was a slightly increase in the amount of woodland area during the study period. Over the long term, grassland has been replaced by scrubland, although this trend has not been linear (grassland areas slightly increases in 1991 compared to 1978), probably because hill fires have regularly destroyed scrublands and spawned the reemergence of grasslands. It is likely that various factors explain the very slow increase in forest cover over the 1978-2004 period, including the forest fires that frequently flare up during the dry, hot season and the fact that some areas are too dry and exposed to the sun for vegetative succession to occur.

As a result of the slight increasing amount of woodland in Hong Kong's country parks, and the gradual sequestration of atmospheric carbon during the 26 years of analysis, the 
amount of carbon sequestered by vegetation and soil in these parks has increased markedly, as shown in Fig. (39).

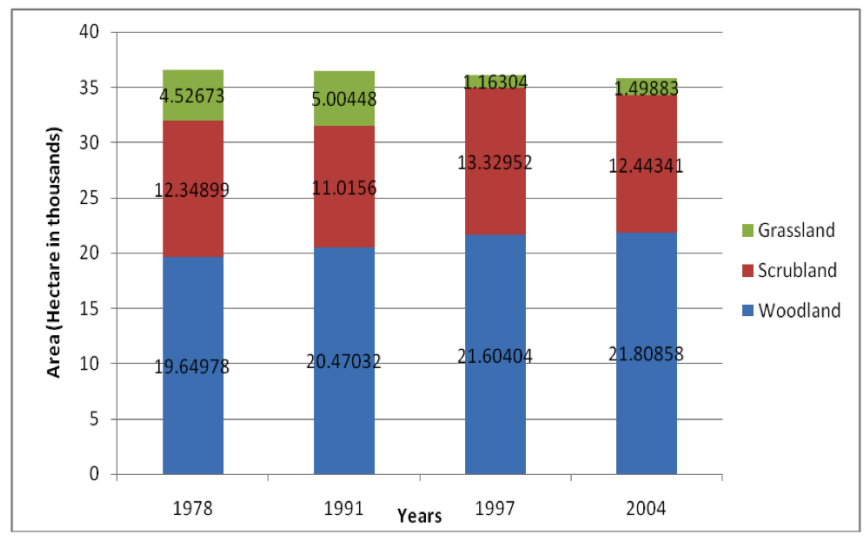

Fig. (38). Distribution of vegetation across all the country parks in Hong Kong.

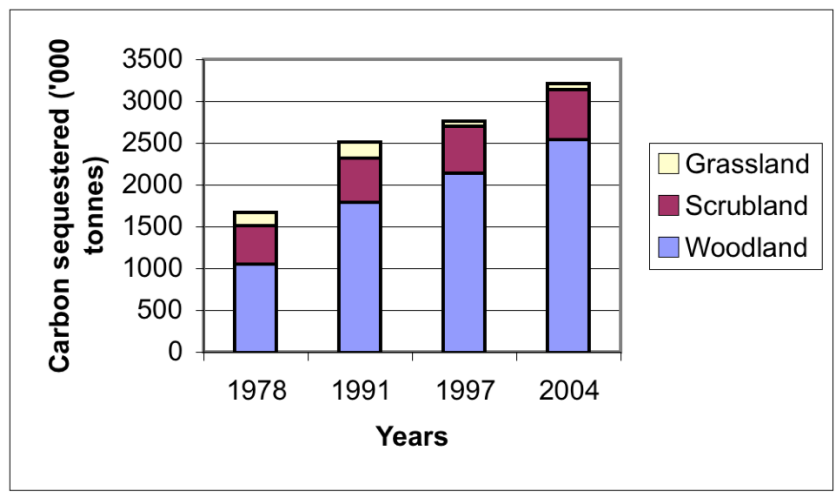

Fig. (39). Total amount of carbon sequestered in all the country parks of Hong Kong.

The total amount of carbon sequestered by the vegetation and soil in the country parks has approximately doubled from 1978 to 2004 (Table 8). Comparing these data to the amounts of carbon supplied by Adams [19] for preanthropogenic ecosystems (Table 2 above), we can conclude that Hong Kong still has a long way to go before the carbon reaches these pre-anthropogenic levels, although our results may be due to the relatively low levels of carbon with which we started our analysis in 1978.

Table 8. Amount of Carbon Sequestered by Hong Kong Country Parks

\begin{tabular}{|c|c|c|}
\hline Year & Carbon Content (Tonnes) & Tonnes Per Hectare \\
\hline \hline 1978 & $1,669,869$ & 45.72 \\
\hline 1991 & $2,507,998$ & 68.73 \\
\hline 1997 & $2,759,789$ & 76.46 \\
\hline 2004 & $3,214,404$ & 89.91 \\
\hline
\end{tabular}

This research has shown the limitations there are in attempting to assess the amount of atmospheric carbon sequestered by vegetation and soil, using remote sensing. These limitations stem from the insufficient information available in terms of carbon sequestration by vegetation and soils, and difficulties in determining the land cover classes.

\section{Carbon Sequestered from Vegetation and Soil}

1. We do not have information on the amount of carbon present in the soil and vegetation of the park, when the park was established in 1978. We assume that in 1978 the carbon in the soil and the vegetation was 75 percent of Adam's [19] pre-anthropogenic figures for grassland and scrubland, and 20 percent of his figures for forestland, but further research might prove these data to be wrong.

2. We assume that the vegetation grows in a linear fashion by $0.5 \mathrm{tC} \mathrm{ha}^{-1} \mathrm{yr}^{-1}$ for grassland and scrubland and $3 \mathrm{tC} \mathrm{ha}{ }^{-1} \mathrm{yr}^{-1}$ for forestland. These estimates are based on a review of the literature, but the same literature shows that the carbon sequestration of different species and in different environments varies enormously. Unfortunately, we do not yet have the data to accurately estimate the carbon sequestered by all species in Hong Kong (listed in Tables 3-7).

3. We should have taken into consideration the fact that younger trees sequester more atmospheric carbon than older trees. Again, no data are available to estimate this with any precision in Hong Kong.

4. It should be reminded that in our calculations we ignore the carbon content of the soil that is not covered by vegetation - which happened in the case of badland, forest fires, or landslides. This is obviously not entirely correct, and in some cases, such as Aberdeen and Pok Lu Lam, Tai Lam, and Tai Mo Shan country parks, this is likely to have had a considerable effect on the amount of carbon sequestered.

\section{Remote Sensing Analysis}

1. There were problems in clipping the images, and in a few cases the quality of the image was rather poor. The total size of all the country parks obtained when adding all vegetation types varied in all four images, with the largest difference being between the images of 1978 (36,525.5 ha) and $2004(35,750.82 \mathrm{ha})$, a reduction of $2.1 \%$. In reality the total size slightly increased, with the addition of the Long Fu Shan Country Park in 1998. The slight decrease shown can be due to: 1) increases in the number of reservoirs and the amount of bare soil with no vegetation due to landslides or hill fires (neither of which are included in the present analysis); 2) problems with the quality of the images used. In particular clouds would be interpreted as badland, landslides, hill fires, or reservoirs and the vegetation underneath ignored. This was a problem for example for Clear Water Bay country park in 1991; and 3) errors in clipping the images of the country parks. The quality of the image - including cloud cover - obviously has a crucial impact on the quality of the results of our study.

2. There might have been problems in the unsupervised classification of the vegetation. The AFCD has conducted tree planting the country parks "for several decades. The number of seedlings planted increased from nearly 650,000 in 2000 to over 900,000 in 2008. Accordingly, there should be an obvious increase in 
the forested area in the country park." (AFCD, pers. comm. 24.07.2009).

3. As mentioned in the introduction, remote sensing analysis of tropical forests is particularly difficult because tropical forests are structurally very complex.

These drawbacks mean that more research is needed before remote sensing can be used to give accurate estimates of the amount of carbon sequestered by vegetation and soils in the country parks, specially if these estimates are used to manage the country parks, or identify both those areas that have to be protected with special care and those areas where selective felling may maximize the amount of carbon sequestration. We hope that this study will also generate interest in further research.

Finally, we should remember that although this paper looks solely at the amount of carbon sequestered from the atmosphere by the soil and the vegetation in Hong Kong country parks, carbon withdrawal is only one of the benefits that these country parks provide. In fact, the country parks were established, and are managed, for watershed services and air purification purposes, and to "protect vegetation and wild life, and provide facilities and services for the public enjoyment, among other objectives" (AFCD, pers. comm. 24.07.2009) rather than for the sequestration of atmospheric carbon. Hence, the success of the country park system should not be judged in terms of the carbon it has been able to remove from the atmosphere. Nevertheless, how much carbon has been sequestered by the soil and vegetation of the country parks is an interesting question that is becoming more and more important as alternative means to sequester atmospheric carbon are explored. It is also a question that has never been asked. In spite of all the drawbacks of this research, this is a first step to try to answer that question.

\section{ACKNOWLEDGEMENTS}

We would like to thank the Department of Geography and Resource Management for gracefully providing the satellite images used in this study, and four anonymous referees for their constructive comments. All remaining mistakes are the responsibility of the authors alone.

\section{REFERENCES}

[1] Cheng HH, Kimble JM. Characterization of soil organic carbon pools. In: Lal R, Kimble JM, Follet RF, Steward BA, Eds. Assessment methods for soil carbon New York: Lewis Publishers 2001; pp. 117-30.

[2] Johnson MG. The role of soil management in sequestering soil carbon. In: Lal R, Kimble JM, Levine E, Steward BA, Eds. Soil Management and Greenhouse Effect. New York: Lewis Publishers 1995; pp. 351-64.

[3] Cheng S. Economic analysis of carbon storage in bottomland hardwoods in the lower Mississippi alluvial valley, Unpublished PhD: Stephen F, Austin State University 2003.

[4] Jong BD, Tipper R, Guillermo MG. An economic analysis of the potential for carbon sequestration by forests: evidence from southern Mexico. Ecol Econ 2000; 33: 313-27.

[5] Goldewijk KK, Leemans R. Systems models of terrestrial carbon cycling. In: Beran MA, Ed. Carbon Sequestration in the Biosphere. Germany: Springer 1995; pp. 129-52.

[6] Goudriaan J. Global carbon cycle and carbon sequestration. In: Beran MA, Ed. Carbon Sequestration in the Biosphere. Germany: Springer 1995; pp. 3-18.
[7] Dixon RK, Krankina ON. Can the terrestrial biosphere be managed to conserve and sequester carbon? In: Beran MA, Ed. Carbon Sequestration in the Biosphere. Germany: Springer 1995; 153-80.

[8] Kirby KR, Potvin C. Variation in carbon storage among tree species: implications for the management of a small-scale carbon sink project. Forest Ecol Manage 2007; 246: 208-21.

[9] Hopkinson L, Stern R. Wild but not free: an economic valuation of the benefits of nature conservation in Hong Kong. Hong Kong: Civic Exchange 2002.

[10] Schlesinger WH. An Overview of the carbon cycle. In: Lal R, Kimble JM, Levine E, Eds. Soils and Global Change. Boca Raton (FL): CRC Press 1995.

[11] Verburg PS, Dam D, Marinissen JC, Westerhof R, Breeman N. The role of decomposition in $\mathrm{C}$ sequestration in ecosystems. In: Beran MA, Ed. Carbon Sequestration in the Biosphere. Germany: Springer 1995; pp. 85-112.

[12] Smith P. Carbon sequestration in croplands: the potential in Europe and the global context. Eur J Agronomy 2004; 20: 229-36.

[13] AFCD. Agriculture, fisheries and conservation department, 2006, Data for each Hong Kong Country Park retrieved November 27, 2008 from the Agriculture, Fisheries and Conservation Department Available at: http://www.afcd.gov.hk/english/country/cou_vis/cou_ vis_cou/cou_vis_cou.html

[14] AFCD. Agriculture, Fisheries and Conservation Department. AFCD Useful Statistics, 2008, Retrieved November 27, 2008 from Hong Kong Government, Agriculture, Fisheries and Conservation Department Available at: http://www.afcd.gov.hk/english/country/ cou_lea/cou_lea_use/cou_lea_use.html

[15] Thrower SL. Hong Kong Country Parks. Hong Kong: Crown 1984.

[16] Vejre H, Callensen I, Vesterdal L, Raulund-Rasmussen K. Carbon and nitrogen in Danish forest soils - contents and distribution determined by soil order. Soil Sci Soc Am J 2003; 67: 335-43.

[17] Grigal DF, Ohmann LF. Carbon storage in upland forests of the Lake States. Soil Sci Soc Am J 1992; 56: 935-43.

[18] Wang S, Huang M, Shao X, Mickler RA, Li K, Ji J. Vertical distribution of soil organic carbon in china. Environ Manage 2004; 33: S200-S9.

[19] Adams J. Potential ecosystem carbon storage, oak ridge national laboratory, environmental sciences division 2009. [Retrieved: November 27, 2008] Available at: http://www.esd.ornl.gov/pro jects/qen/carbon $3 . h t m l$

[20] Cannell MGR, Cruickshank MM, Mobbs DC. Carbon storage and sequestration in the forests of Northern Ireland. Forestry 1996; 69(2): 155-65.

[21] Cannell MGR. Relative importance of increasing atmospheric $\mathrm{CO} 2, \mathrm{~N}$ deposition and temperature in promoting European forest growth. In: Karjalainen T, Spiecker H, Laroussinie O, Eds. Causes and Consequences of Accelerating Tree Growth in Europe. Joensuu (Finland): European Forest Institute, European Forest Institute Proceedings 1999; pp. 25-41.

[22] Milne R, Brown TAW. Mapping of carbon uptake in British woodlands and forests using EuroBiota and C-Flow. In UK Emissions by Sources and Removals by Sinks due to Land Use. Land Use Change and Forestry Activities. Edinburgh: Report, Centre for Ecology \& Hydrology 2002.

[23] Achard F, Eva HD, Mayaux P, Stibig HJ, Belward A. Improved estimates of net carbon emissions from land cover change in the tropics for the 1990s. Global Biogeochem Cycles 2004; 18(2): Aft No. GB2008.

[24] van Kooten G, Arthur L, Wilson W. Potential to sequester carbon in Canadian forests: some economic considerations. Canadian Public Policy 1992; 18(2): 127-38.

[25] Brainard J, Lovett A, Bateman I. Carbon sequestration benefits of Woodland. Report to the Forestry Commission. Soc Environ Benefits Forestry (Phase 2) 2003.

[26] Sedjo R, Solomo, A. Greenhouse Warming: Abatement and Adaptation'. In: Crosson P, Darmstadter J, Easterling W, Rosenberg N, Eds. RFF Proceedings 1989; pp. 110-9.

[27] Nordhaus W. The cost of slowing climate change: a survey. Energy J 1991; 12(1): 37-65.

[28] Hultman NE. Carbon financial risk in the International Greenhouse Gas Market. Unpublished PhD. Berkeley: University of California 2003. 
[29] Gibbs HK, Brown S, Niles JO, Foley JA. Monitoring and estimating tropical forest carbon stocks: making REDD a reality. Environ Res Lett 2007; 2: 1-13.
[30] WSD, Water Supply Department Available at: http://www.wsd. gov.hk, 2009

(C) Delang and Hang; Licensee Bentham Open.

This is an open access article licensed under the terms of the Creative Commons Attribution Non-Commercial License (http://creativecommons.org/licenses/by$\mathrm{nc} / 3.0 /$ ) which permits unrestricted, non-commercial use, distribution and reproduction in any medium, provided the work is properly cited. 